\title{
Effects of silver nanoparticles of different sizes on cytotoxicity and oxygen metabolism disorders in both reproductive and respiratory system cells
}

\author{
Lidia Zapór \\ Central Institute for Labour Protection - National Research Institute, Poland \\ *Corresponding author's e-mail: lizap@ciop.pl
}

Keywords: silver nanoparticles, cytotoxicity, reactive oxygen species, DNA damage.

\begin{abstract}
Silver nanoparticles (AgNPs) are widely used in numerous industries and areas of daily life, mainly as antimicrobial agents. The particles size is very important, but still not sufficiently recognized parameter influencing the toxicity of nanosilver. The aim of this study was to investigate the cytotoxic effects of AgNPs with different particle size $(\sim 10,40$ and $100 \mathrm{~nm})$. The study was conducted on both reproductive and pulmonary cells (CHO-9, 15P-1 and RAW264.7). We tested the effects of AgNPs on cell viability, cell membrane integrity, mitochondrial metabolic activity, lipid peroxidation, total oxidative and antioxidative status of cells and oxidative DNA damage. All kinds of AgNPs showed strong cytotoxic activity at low concentrations $(2 \div 13 \mu \mathrm{g} / \mathrm{ml})$, and caused an overproduction of reactive oxygen species (ROS) at concentrations lower than cytotoxic ones. The ROS being formed in the cells induced oxidative damage of DNA in alkaline comet assay. The most toxic was AgNPs $<10 \mathrm{~nm}$. The results indicate that the silver nanoparticles, especially less than $10 \mathrm{~nm}$, may be harmful to the organisms. Therefore, risk should be considered when using nanosilver preparations and provide appropriate protective measures when they are applied.
\end{abstract}

\section{Introduction}

Nanosilver, mainly due to the antimicrobial properties, is widely used in numerous industries and areas of daily life. Silver nanoparticles (AgNPs) are used in biomedicine (as antibacterial agents, antibacterial coatings, disinfectants for medical devices); in chemical industry (paints, varnishes, adhesives, polymers); in cosmetics and care products (soaps, toothpaste); in food product packaging; in home appliances (refrigerators, washing machines, air-conditioners with nanosilver-containing coatings); in items of clothing (socks), and many others (Luoma 2008, Senjen et al. 2009, SCENIHR 2014, EPA 2015). Hundreds of nanosilver products are currently on the market, and their number is growing rapidly. It is estimated, that annual quantities of AgNPs introduced to the global market are around 20 tonnes (SCENIHR 2014). A significant quantity of nanosilver released from professional use and consumer products gets into the natural ecosystems (EPA 2015). Silver nanoparticles may be released to the environment from discharges at the point of production, from erosion of engineered materials in household products, and from washing or disposal of silver-containing products (Marambio-Jones and Hoek 2010). Release into the surrounding environment results in changes to AgNPs properties via oxidation and sulfidation. More recent studies of the pathway of chemical transformations of nanosilver in different environmental compartments demonstrated that AgNPs are bound strongly to sulfur (both organic and inorganic) in natural systems (fresh and sea waters) as well as in wastewater treatment plants and biosolids, where most Ag-NPs are concentrated as $\mathrm{Ag}_{2} \mathrm{~S}$ (Kim 2010, Kaegi 2011, 2013, Levard 2011, Impellitteri 2013, Schlich et al. 2013). Sulfidation of Ag-NPs on the one hand results in a significant decrease in their toxicity due to the lower solubility of $\mathrm{Ag}_{2} \mathrm{~S}$ (Levard 2013), but on the other hand, $\mathrm{Ag}_{2} \mathrm{~S}$ can be deposited in environment (for example in sediments or soil) for a long time, being the source of very toxic silver ions (Kim 2010, Kaegi 2011, 2013).

Most of AgNPs are expected to be concentrated and released in wastewater treatment plants and finally in sewage sludge where they could pose a risk for the aquatic ecosystems. Biosolids recycled from sewage are incinerated or applied as an agricultural fertilizer, and represent an important route of exposure of ecosystems to AgNPs (Colman et al. 2013, Schlich et al. 2013). It has been shown that AgNPs can cause adverse effects to both aerobic and anaerobic bacteria in wastewater treatment plants (Choi and $\mathrm{Hu} 2008$ ). Numerous studies also confirm that $\mathrm{Ag}$ originating from the NPs is bioavailable to aquatic and terrestrial organisms (algae, fungi, crustacean, slugs, insects, nematodes, gastropoda, fish and plants) resulting in bioaccumulation and bio-magnification in food chains (Luoma 2008, Senjen et al. 2009, Marambio-Jones and Hoek 2010 and references therein, SCENHIR 2014, Sohn et al. 2015). 
Another environment in which AgNPs could pose a significant risk is the work environment (SCENIHR 2014). Workplace exposure can occur at production, use, when machining materials and from waste, and depends on the work procedure and applied risk management measures. In particular, exposure to aerosols may be important for health. It was shown that even during a short-term spraying of nanosilver preparation (for $10 \mathrm{~s}$ ) at the distance of $52 \mathrm{~cm}$ from the place of preparation spraying - particles of $10 \mathrm{~nm}-10 \mu \mathrm{m}$ can be emitted into the air (Jankowska and Łukaszewska 2013).

Nanosilver has for years been of interest to toxicologists. However, despite the results of numerous studies, the issue of nanosilver toxicity is still unresolved (Senjen et al. 2009, Luoma 2008). The main knowledge gaps are related to toxicokinetics data. There is a lack of consensus on the underlying mechanisms that drive the toxicity of AgNPs - the particles per se, the released Ag ionic species, or their combination (Wijnhoven et al. 2009, Marambio-Jones and Hoek 2010, Beer et al. 2012, Cronholm 2013, Gliga et al. 2014).

Scientific research indicates that AgNPs are able to interfere with cellular functions and cause toxic effects, including DNA damage and apoptosis in mammalian cells. In vitro assays demonstrated toxic effects on macrophages, lung epithelial cells, stem cells, liver cells, neuronal cells, osteoblasts and many others (Arora et al. 2008, 2009, Asare et al. 2012, AshaRani et al. 2009, Hussain et al. 2005, Kim et al. 2010, Moaddab et al. 2011, Mukherjee et al. 2012). As regards the mechanisms of toxic effects of silver nanoparticles, the influence on the formation of free radicals is primarily mentioned. The participation of reactive oxygen species in the mechanism of nanosilver activity is indicated by the results of the in vivo and in vitro studies (Wijnhoven et al. 2009, Marambio-Jones and Hoek 2010). According to numerous reports, the overproduction of free radicals, which leads to oxidative stress, is caused by ions being released from silver nanoparticles, including by a Trojan horse - type mechanism (Carlson et al. 2008, Manke et al. 2013, Park et al. 2010, Singh and Ramaro 2012). On the other hand, some studies demonstrated that AgNPs toxicity is primarily the result of oxidative damage and is independent of the toxicity of $\mathrm{Ag}+$ ions (Kim et al. 2009, Verano-Braga 2014).

The size of nanoparticles is, generally, one of the most important factors influencing their toxicity. Silver nanoparticles being most widely used in the industry are those with a size of 1-50 nm (Senjen 2009). Studies on toxic effects of metal nanoparticles indicate that small particles, especially those below $10 \mathrm{~nm}$ in size, may circulate freely within the body and reach particular internal organs such as liver, spleen, kidneys, lungs, and even reproductive system (Commission... 2012). However, nanoparticles in culture media used in the in vitro assays form aggregates and agglomerates, especially those nanoparticles which are supplied in a form of powders. This property of nanoparticles impedes the assessment of their toxicity (Lankoff et al. 2012, Vippola et al. 2009). Despite numerous in vitro assays confirming toxicity of nanosilver to mammalian cells, the data on toxicity of AgNPs depending on the particle size are rather scarce and often inconclusive. In most of studies, the size-dependent relations were tested with AgNPs with large differences between diameters e.g. 10 and $100 \mathrm{~nm}$ or 20 and $200 \mathrm{~nm}$ (Kruszewski et al. 2013, Wang et al. 2012, Jiao et al. 2014). The results of some studies indicate that smaller AgNPs have a stronger effect (Kim et al. 2012, Park et al. 2010, 2011, Gliga et al. 2014, Liu et al. 2010). This is in disagreement with the results of Hussain et al. (2005) obtained from rat liver cells (BRL 3A) which demonstrated a substantial difference as regards the toxic effects of nanosilver particles of 15 and $100 \mathrm{~nm}$, with the bigger particles $(100 \mathrm{~nm})$ exhibited greater toxicity. In turn, Jiao et al. (2014) reported that $10 \mathrm{~nm}$ and $100 \mathrm{~nm}$ AgNPs at the same mass did not exhibit dramatic differences in cell proliferation or p38 activation in HepG2 cells.

The differences in the results of the cited research prompted us to assess the size-dependent toxicity of silver nanoparticles. Particularly interesting for us was whether or not the most extensively used silver nanoparticles (size of 1-50 nm) had stronger toxic effects than those of bigger particles. For this purpose, we selected AgNPs with a nominal size of 10,40 and $100 \mathrm{~nm}$. Given the methodological difficulties in ensuring homogeneity of nanoparticle dispersions (due to agglomeration and aggregation), silver nanoparticles in aqueous buffer, containing sodium citrate as a stabilizer were used. This citrate-based agent was selected because, according to the manufacturer, it provides long term stability, minimizes the release ionic by-product in the supernatant, and is readily displaced by various other molecules including thiols, amines, polymers, antibodies, and proteins (www.sigmaaldrich.com). Additionally, the recent studies indicate a negligible role of citrate buffer in the toxicity of AgNPs (Gliga et al. 2014, Miethling-Graff et al. 2014, Sheehy et al. 2015).

The studies were performed on both pulmonary and reproductive system model cells, i.e. on murine lung macrophages (RAW264.7) originating from the BALB/c strain, and on Chinese hamster ovary cells (CHO-9) and Sertoli cells (15P-1) originating from the testes of transgenic mice. The studies on the effects of AgNPson reproductive system may be of particular significance in the assessment of health risks, in particular for the assessment of long-term consequences of exposure. Sertoli cells belong the category of so-called barrier cells - they are involved in the formation of the blood-testis barrier which isolates the postmeiotic gametes from the environment of the body (also from the impact of mutagenic agents), and are capable of phagocytosis. Chinese hamster ovary cells are a proven line with high sensitivity to xenobiotics, including metals. Macrophages perform protective functions in the body, being fulfilled through, inter alia, the phenomenon of phagocytosis. Macrophages are also involved in the initiation and sustaining of inflammatory processes and in immunological reactions, and are considered to be particularly suitable to nanoparticle testing (Hussain et al. 2005).

Prior to testing, nanoparticles were characterized in terms of particle size and particle size distribution using Dynamic Light Scattering (DLS) and Nanoparticle Tracking Analysis (NTA) methods. The following end-points were tested: effects of AgNPs on cell viability, cell membrane integrity, and cellular lysosomal activity (NRU assay); mitochondrial metabolic activity (MTT assay); lipid peroxidation process by measurements of thiobarbituric acid reactive substances (TBARS assay); total oxidative status (TOS assay) and total antioxidative status (TAS assay); DNA breakage estimated by the comet assay and oxidative base damage recognized by formamido-pyrimidine glycosylase (FPG). 


\section{Materials and methods}

\section{Chemicals and reagents}

For cell cultures were used: Dulbecco's modified Eagle's medium (DMEM), F-10 (Ham) medium with L-glutamate, fetal bovine serum (FBS) and Antibiotic-Antimycotic from Gibco BRL (Life Technologies Ltd. Paisley, UK). Trypsin-0.02\% EDTA solution $(0.25 \%)$ and $0.4 \%$ trypan blue stain were purchased from Sigma Chemical Co. (St Louis, MO, USA).

For cytotoxicity assays were used: 3-(4,5 dimethylthiazol-2-yl)-2,5 diphenyltetrazolium bromide (MTT), Neutral Red Solution (NRU); Hank's Balanced Salt Solution, Dulbeco's Phosphate Buffered Saline, dimethylsulphoxide (DMSO) from Sigma; glacial acetic acid $(100 \%)$ from Merck (Darmstadt, Germany); ethanol (96\%) from POCH (Poland).

Oxidative/antioxidative potential in cells was determined with the PerOx (TOS/TOC) and ImAnOx (TAS/TAC) Test Kits, manufactured by Immundiagnostic AG (Immundiagnostic AG, Stubenwald-Allee 8a, D 64625 Bensheim). Lipid peroxidation was determined by measurements of thiobarbituric acid - reactive substances (TBARS Test) from Cell Biolabs, Inc. Protein concentration in samples was determined by Bradford's method with a test kit manufactured by Sigma.

All reagents for alkaline comet assay were purchased from Sigma. Formamido-pyrimidine glycosylase (FPG) was supplied by New England BioLabs.

Silver nanoparticles (AgNPs) in trisodium citrate-stabilized suspension with nominal particle size below 10, 40, and $100 \mathrm{~nm}$ (marked in the text: $\operatorname{AgNPs}<10, \operatorname{AgNPs}_{\mathbf{s}}<40$, AgNPs $<100$ ), were purchased from Sigma-Aldrich (Cat. No.: 730785; 730807 and 730777 respectively). The mass concentration of AgNPs was $0.02 \mathrm{mg} / \mathrm{ml}$ in $2 \mathrm{mM}$ citrate buffer. The particles were characterized by the manufacturer in terms of diameter and size distribution, spectral properties and TEM analysis.

\section{Preparation and characterization of AgNPs suspensions}

The particle size distribution $\left(\operatorname{AgNPs}_{\mathrm{s}}<10, \operatorname{AgNPs}_{\mathrm{s}}<40\right.$, AgNPs $<100$ ) was carried out using the Dynamic Light Scattering (DLS) method (Zetasizer Nano-ZS, Malvern, UK) and by Nanoparticle Tracking Analysis (NTA) (NS500, Nanosight Ltd., UK). All these measurements were carried out at the Institute of High Pressure Physics of the Polish Academy of Sciences (Warsaw).

A solution of a given concentration was prepared immediately before toxicity testing in culture medium appropriate to the serum-free cell line. The solution (slurry) was stirred and sonicated at high energy level of $420 \mathrm{~J} / \mathrm{cm}^{3}$ for $5 \mathrm{~min}$. to ensure homogeneity (Bandelin, Sonorex RK225H).

\section{Cell culture and treatment}

The line of Chinese hamster's ovary cells CHO-9 was kindly provided by the Institute of Biochemistry and Biophysics of the Polish Academy of Science in Warsaw, the mouse macrophage-like cell line RAW264.7 (No. Cat. TIB-71) and Sertoli cell line 15P-1 (No. Cat. CRL-2618) were purchased from American Type Culture Collection (LGC Standards Sp. $\mathrm{z}$ o.o.). The cells were cultured as a monolayer in a complete DMEM (RAW264.7 and 15P-1) or F-10 (CHO-9) medium supplemented with $10 \%$ FBS and with $1 \%$ antibiotic- -antimycotic in sterile tissue culture flasks (Nunc, USA) and maintained at $37^{\circ} \mathrm{C}$ in a humidified atmosphere with $95 \%$ air: $5 \% \mathrm{CO}_{2}$ and $\mathrm{pH} 7.2-7.4$. For subculturing, the cultures were trypsinised with $0.25 \%$ trypsin- $0.02 \%$ EDTA. They were subcultured twice a week when $90 \%$ confluence was reached. For the experiments the cells were used between passages 20 and 45. The cells were screened for Mycoplasma sp. infection using MycoAlert ${ }^{\mathrm{TM}}$ PLUS Mycoplasma Detection Kit (Lonza, Walkersville, Inc.). Before starting the experiment, the cells were removed from the flask by trypsinisation and cell suspension was prepared. Cell number and cell viability were determined in a Bürker chamber by the trypan blue exclusion method. Cells whose viability was over $90 \%$ were used in experiments. Before performing the toxicity tests of AgNPs, the toxic effect of sodium citrate $[2 \mathrm{mM}]$ for all tested parameters was assessed.

\section{Cell cytotoxicity assays}

To assess cytotoxicity of AgNPs the neutral red uptake (NRU) and MTT reduction assays were performed according to INVITTOX Protocol No. 64 and No. 17, respectively. Cells were plated at a density of $1 \times 10^{5} /$ well in a 96 -well culture plate and cultured overnight to allow adherence and recovery. After this period, non-attached cells were aspirated and test compounds in different concentrations were added, than incubated for $24 \mathrm{~h}$. For all AgNPs the concentration ranges of $0.5 \div 15 \mu \mathrm{g} / \mathrm{ml}$ were used $(0.5,1.0,2.0,4.0,6.0,8.0,10.0,12.0,15.0 \mu \mathrm{g} / \mathrm{ml})$.

For NRU assay the medium with tested chemicals was removed, cells were washed with PBS to avoid any interference in light absorption due to the particles and medium-containing neutral red dye $\left(50 \mu \mathrm{g} / \mathrm{cm}^{3}\right)$ was added to each well $(100 \mu \mathrm{l})$. After incubation for 3 hours, supernatants were removed and cells were fixed with $100 \mu \mathrm{l}$ of $1 \%$ glacial acetic acid-50\% ethanol- $49 \%$ distillate water. The plates were left at room temperature for $10 \mathrm{~min}$ and shaken. Then absorption was measured using SYNERGY 2 (BioTek Instruments, Inc.) microplates reader (at $540 \mathrm{~nm}$ against a $450 \mathrm{~nm}$ filter).

For MTT assay, after removing the medium with tested chemicals, the cells were washed with PBS and medium-containing MTT (5 mg/cm ${ }^{3}$ in Hank's buffered saline) was added to each well $(100 \mu \mathrm{l})$. After incubation for 3 hours, supernatants were removed and the violet formazan product obtained (by reduction of the MTT) was dissolved in $100 \mu \mathrm{l}$ of pure DMSO. The plates were then shaken and absorption was measured using SYNERGY 2 (BioTek Instruments, Inc.) microplates reader (at $570 \mathrm{~nm}$ against a $620 \mathrm{~nm}$ filter). Cytotoxicity tests were performed in at least three independent experiments (6 replications of each concentration in the experiment). Based on the absorbance measurement values obtained in MTT and NRU tests, the viability ratio of cells exposed to the tested compounds, i.e. the percentage of viable cells compared to control (100\%), was calculated, followed by calculation of concentrations of the tested substances that reduced cell viability by $50 \%$ compared to control $\left(\mathrm{IC}_{50}\right)$.

\section{Lipid peroxidation assessment}

Lipid peroxidation was assessed by determining the quantities of products identified as thiobarbituric acid-reactive substances (TBARS), in line with the manufacturer-supplied protocol. To assess lipid peroxidation we used the following concentrations of AgNPs: 3, 6 or $10 \mu \mathrm{g} / \mathrm{ml}$ for RAW264.7 and 5, 10 or $12 \mu \mathrm{g} / \mathrm{ml}$ for CHO-9 and 15P-1. In order to carry out the determination 
of TBARS in cells exposed to AgNPs and non-exposed cells (control group), a suspension of $1-2 \times 10^{7}$ cells $/ \mathrm{ml}$ was prepared in PBS and placed in a deep freezer $\left(-70^{\circ} \mathrm{C}\right)$. Following three thaw/freeze cycles to in order to lyse the product, the entire lysate was used for determinations: $250 \mu$ of thiobarbituric acid was added to $200 \mu \mathrm{l}$ of the test sample and incubated for 60 minutes at $95^{\circ} \mathrm{C}$. Next, the cells were cooled down to room temperature in an ice bath for 5 minutes, centrifuged at 3,000 rpm for 15 minutes and $200 \mu \mathrm{l}$ aliquots of the supernatant were transferred onto a 96-well plate used for determination of light absorbance at $\lambda=532 \mathrm{~nm}$ relative to the blank sample. The TBARS concentrations in the tested sample were determined from the reference curve prepared according to manufacturer protocol and normalized for the total protein content (Bradford's method).

\section{Assessment of total oxidative/antioxidative status (TOS/TAS) of cells exposed to AgNPs.}

To assess total oxidative/antioxidative potential of AgNPs the same concentrations as in TBARS test we used. After a 24-h exposure to the test compounds, the cells were lysed by freezing at $-80^{\circ} \mathrm{C}$ (in the three thaw/freeze cycles). Before determinations of the oxidative/antioxidative status, cells were thawed, sonicated (30 min.) and then centrifuged (13,000 rpm). Measurements were performed by colorimetric method in 96-well microplates. The absorbance of the dye was measured at the wavelength of $450 \mathrm{~nm}$ using SYNERGY 2 microplates reader. Each experiment was performed in at least three replications.

The total oxidative status (TOS) of cells exposed to the tested compounds was determined by means of measuring the total levels of lipid peroxides in cells according to the PerOx (TOS/TOC) Kit protocol supplied by the manufacturer. The levels of peroxides in the tested samples were determined by the reaction of horseradish peroxidase with tetramethylbenzidine (TMB) dichloride in the presence of hydrogen peroxide. The reaction with the enzyme yields a soluble, blue-coloured product. The enzymatic reaction is quenched by adding $2 \mathrm{M}$ $\mathrm{H}_{2} \mathrm{SO}_{4}$, which leads to the solution changing its colour to yellow. Using the measured absorbance values, total levels of peroxides in tested samples $\left[\mathrm{mmol}_{2} \mathrm{O}_{2}\right]$ were determined according to the formula provided by the manufacturer, and then converted to milligrams of protein in individual samples.

The total antioxidative status (TAS) of cells was determined in the reaction of antioxidants with a pre-defined (known) amount of exogenous hydrogen peroxide $\left(\mathrm{H}_{2} \mathrm{O}_{2}\right)$ according to the ImAnOx (TAS/TAC) Kit protocol supplied by the manufacturer. Antioxidants react with the peroxide, and the amount of unreacted $\mathrm{H}_{2} \mathrm{O}_{2}$ is measured spectrophotometrically (similar as in the PerOx test). The difference between the added and the measured amount of $\mathrm{H}_{2} \mathrm{O}_{2}$ (relative to the calibrator supplied by the manufacturer) is proportional to the antioxidant activity.

Using the measured absorbance values, total antioxidative status expressed in $\mu \mathrm{mol} / \mathrm{L}$ was determined according to the formula provided by the manufacturer. The obtained value was converted to milligrams of protein in the sample.

\section{Alkaline comet assay}

The alkaline comet assay (Single Cell Gel Electrophoresis, SCGE) was performed as described by Wojewodzka et al. (1998). The measurements were carried out at the Institute of Nuclear Chemistry and Technology in Warsaw.
Silver nanoparticles AgNPs $<100 \mathrm{~nm}$, at concentrations of 2 and $4 \mu \mathrm{g} / \mathrm{ml}$, were studied on CHO-9 cells. The cells were incubated with AgNPs for $24 \mathrm{~h}$. in a 6-well culture plate $(3 \mathrm{ml}$ of medium in a well). Next, the cells were separated from the medium, suspended in culture medium (approx. $1.5 \mathrm{ml}$ of medium, 0.5 million cells $/ \mathrm{ml}$ ), and mixed with $2 \%$ low melting point agarose (Sigma Type VII) as dissolved 1:1 in PBS. The cells in agarose were placed onto a microscope slide, covered with a cover slip and located on a chilled metal plate. After the agarose has solidified, the cover slip was removed, and the microscope slides were immediately placed in a lysis buffer (2.5 M NaCl, $100 \mathrm{mM}$ EDTA, 10 mMTris, 1\% Triton X-100, $\mathrm{pH}=10$ ) for $1 \mathrm{~h}$ at a temperature of $4^{\circ} \mathrm{C}$ in the dark. Then, the slides were placed in an electrophoresis apparatus in electrophoresis buffer: $300 \mathrm{mMNaOH}, 1 \mathrm{mM}$ EDTA (Sigma), and incubated for $40 \mathrm{~min}$ at a temperature of $5-6^{\circ} \mathrm{C}$ in order to denature DNA. Electrophoresis was carried out for $30 \mathrm{~min}$ at $30 \mathrm{~V}$ at a temperature of $5-6^{\circ} \mathrm{C}$. All stages of slide preparation and electrophoresis were carried out under red light in order to secure cells against damage. After the electrophoresis, the slides were washed three times with a neutralizing buffer $(0.4 \mathrm{M}$ Tris, $\mathrm{pH}=7.5)$, and then the preparations were stained with a $1 \mathrm{mM}$ DAPI (Sigma) solution, and covered with a cover slip. The preparations were left in a closed box as lined with moisture filter paper, in a refrigerator, for approx. 24 hours. Thus prepared slides were subjected to computerized image analysis.

As regards the determination of oxidative damage recognized by FPG, the cells on slides, after having been removed from the lysis buffer, were washed 3 times for $5 \mathrm{~min}$ in an enzyme dilution buffer: $40 \mathrm{mM}$ HEPES, $0.1 \mathrm{M} \mathrm{KCl}$, $0.5 \mathrm{mM}$ EDTA, $0.2 \mathrm{mg} / \mathrm{ml} \mathrm{BSA}, \mathrm{pH}=8.0$. After the last wash, excess buffer was drained using filter paper. $60 \mu \mathrm{l}$ of either diluted enzyme $(1: 10,000)$ or the buffer alone in the control were sprinkled over the slide, and covered with a cover slip. The slide was incubated in a humid chamber for $30 \mathrm{~min}$ at a temperature of $37^{\circ} \mathrm{C}$.

An analysis of the computerized image was conducted using the software Comet Assay IV Image Analysis System from Perceptive Instruments Ltd.

For the assessment of the degree of DNA damage, two parameters were applied: percentage of DNA in the tail, and the tail moment, i.e. the product of the percentage of DNA in the tail times the length of the comet tail.

\section{Statistical Analysis}

At least three independent experiments were conducted for cytotoxicity endpoint and oxidative metabolism disturbance. The $\mathrm{IC}_{50}$ values were evaluated based on the analysis of a series of dose-response curves, for each compound using nonlinear regression analysis at 95\% confidence interval (concentrations reducing cell viability by $50 \%$ as compared with the control). The results of all tests were presented as mean values, \pm standard deviation (SD). Conformity of the distribution of the results $\left(\log \mathrm{IC}_{50}\right)$ with the normal distribution was examined with the Kolmogorov-Smirnov test. The significance of differences between distributions of $\log \mathrm{IC}_{50}$ values was evaluated with the Student's t-test for the $\log \mathrm{IC}_{50}$ values which met the criteria of normal distribution or by Wilcoxon's test for those which did not. TOS/TAS and TBARS data were analyzed by Student's test for comparison between two groups. Differences were considered statistically significant when $p<0.05$. The results of 
comet assay were presented as mean values as obtained from five experiments, \pm standard deviation (SD). The significance of differences between the mean values was assessed using the paired Student's $t$-test. Differences were considered statistically significant when $\mathrm{p}<0.05$. The software employed for statistical analysis was Statistica, version 7.1.

\section{Results}

\section{Characterisation of silver nanoparticles based on DLS and NTA methods}

The silver particles used, have a nominal size of 10,40 , and $100 \mathrm{~nm}$, defined by the manufacturer using transmission electron microscopy (TEM) images, dynamic light scattering, Zeta potential measurements, and UV/Visible spectral analysis (SIGMA, www.sigmaaldrich.com).

An analysis of measurements of the particle size distribution using the DLS and NTA methods conducted before experiments, confirmed differences between the three dispersions of AgNPs. The size histograms of the particles are illustrated in Figures 1-3.

The size distribution of $\operatorname{AgNPs}<10$ indicates that hydrodynamic diameters of particles were larger than their nominal particle sizes. Three main peaks were visible: 6, 11 and $36 \mathrm{~nm}$ (bigger particles were also found). This suggests that $\operatorname{AgNPs}<10$ had strong tendency to form aggregates/agglomerates. The results obtained with NTA analysis were confirmed by DLS method (Fig. 1A, 1B).

The most monodisperse suspension was AgNPs $<40 \mathrm{~nm}$ (the index of polydyspersity was equal to 0.124 ). The particles had an average diameter $44 \mathrm{~nm} \pm 12 \mathrm{~nm}$ (Mode $=38 \mathrm{~nm}$ ). Approx. $50 \%$ of all particles were those with a diameter of up to $40 \mathrm{~nm}$, with $90 \%$ of particles not exceeding the level of $60 \mathrm{~nm}$ (Fig. 2A, 2B).

The suspension of $\mathrm{AgNPs}<100$ was also characterized by a low degree of dispersion (the index of polydispersity was equal to 0.057), contained a small amount of particles of above $100 \mathrm{~nm}$ (up to approx. 9\%), and only up to approx. $20 \%$ of particles with a diameter of below $30 \mathrm{~nm}$. The average size of particles was $99 \mathrm{~nm}$, with $50 \%$ of the suspension being particles of up to $70 \mathrm{~nm}$ (Fig. 3A, 3B).

\section{Cytotoxicity assessment}

The cytotoxicity of AgNPs was examined by determining their effects on cell membrane integrity and permeability (NRU assay), and on the mitochondrial metabolic activity (MTT assay) of the cells after $24 \mathrm{~h}$ exposure. The comparison of cytotoxicity (expressed as $\mathrm{IC}_{50}$ values) is presented in Figure 4. The $\mathrm{IC}_{50}$ values are provided in labels above histograms.

All kinds of AgNPs showed strong cytotoxic activity at low doses (within the range of $2 \div 13 \mu \mathrm{g} / \mathrm{ml}$ ). The $\operatorname{AgNPs}<10$

A)

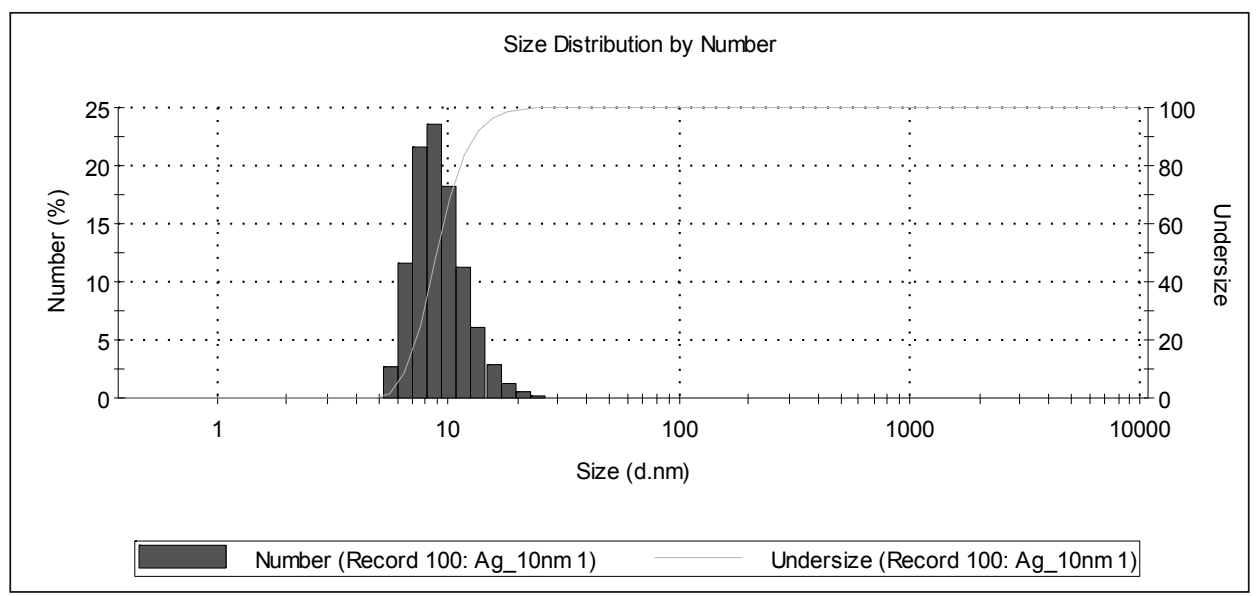

B)

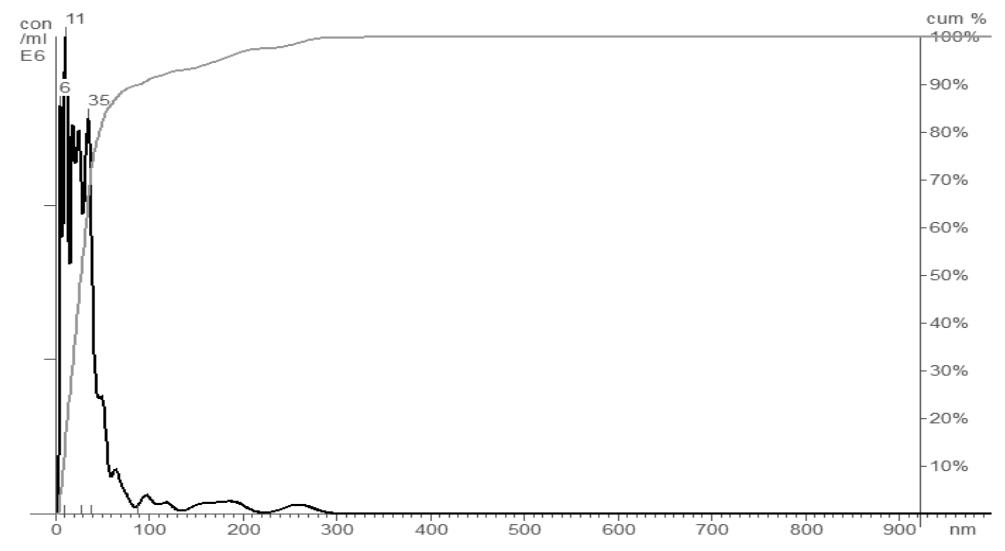

Mean: $43 \mathrm{~nm}$,

Mode: $11 \mathrm{~nm}$,

SD: $50 \mathrm{~nm}$

Fig. 1. Size distribution by number (in \%) of AgNPs $<10$ in DLS (A) and NTA (B) method 
had a stronger cytotoxic effect as compared to $\mathrm{AgNPs}<40$ and $\mathrm{AgNPs}_{\mathrm{s}}<100$. This effect was most evident in $\mathrm{CHO}$ cells. The AgNPs $<40$ and AgNPs $<100$, caused a similar toxic effect on all cell lines, which was assessed using both MTT and NRU assay (with exception the results obtained for AgNPs $<100$ on CHO cells in NRU test).

\section{Lipid peroxidation assessments}

The levels of thiobarbituric acid reactive substances (TBARS) being formed in cells following exposure to AgNPs are presented in Figure 5. All kind of sizes of AgNPs caused an increase in the level of TBARS already at the lowest of the concentrations applied (below the $\mathrm{IC}_{50}$ values) as compared to the control. The TBARS levels depended on the type of cells. In tests on macrophages, AgNps $<10$ and AgNPs $<40$ caused a comparable increase in the TBARS level, being dependent on the concentration, while following exposure to $\mathrm{AgNPs}<100$, the amount of TBARS was maintained at a similar low level (Fig. 5A). In CHO-9 cells being exposed to $\operatorname{AgNPs}<40$ or $\operatorname{AgNPs}^{2}<100$, an increase was observed in the TBARS level, being small as compared to the control, while following exposure to $\operatorname{AgNPs}_{\mathbf{s}}<10$, the increase in the TBARS level was concentration dependent and reached very high values (approx. 8 times higher than in the control) (Fig. 5B). As regards 15P-1 cells, all AgNPs caused the release of TBARS at a similar level (approx. 3 times higher in relation to the control, at concentrations being close to $\mathrm{IC}_{50}$ ) (Fig. 5C).

\section{Total oxidative status assessment}

A comparison of the total oxidative potential (TOS) of the compounds under study, understood as a capacity to produce reactive oxygen species, being assessed on the basis of the total concentration of lipid peroxides in cells, is presented in Figure 6. The oxidative potential of AgNPs depended on the type of cells. The highest TOS values were observed on RAW264.7 cells, while the lowest on 15-P cells. All kinds of AgNPs caused dose-dependent increase in the total concentration of lipid peroxides in cells as compared to the control. This increase was already observed at low concentrations (below $\mathrm{IC}_{50}$ values). In the studies on RAW264.7 and CHO-9 cells the AgNPs $<40$ and AgNPs $<100$ at equivalent concentrations, exhibited a comparable oxidant potential. The highest TOS values were observed in both RAW264.7 and CHO-9 exposed to AgNPs in the highest concentration. Such regularity did not confirm the results obtained on 15.P cells.

\section{Total antioxidative status assessment}

In all cells being exposed to AgNPs, an increase in the total antioxidative potential (TAS) as compared to the control was observed, however, this increase was in the most cases independent of the sizes of AgNPs and their concentrations

A)

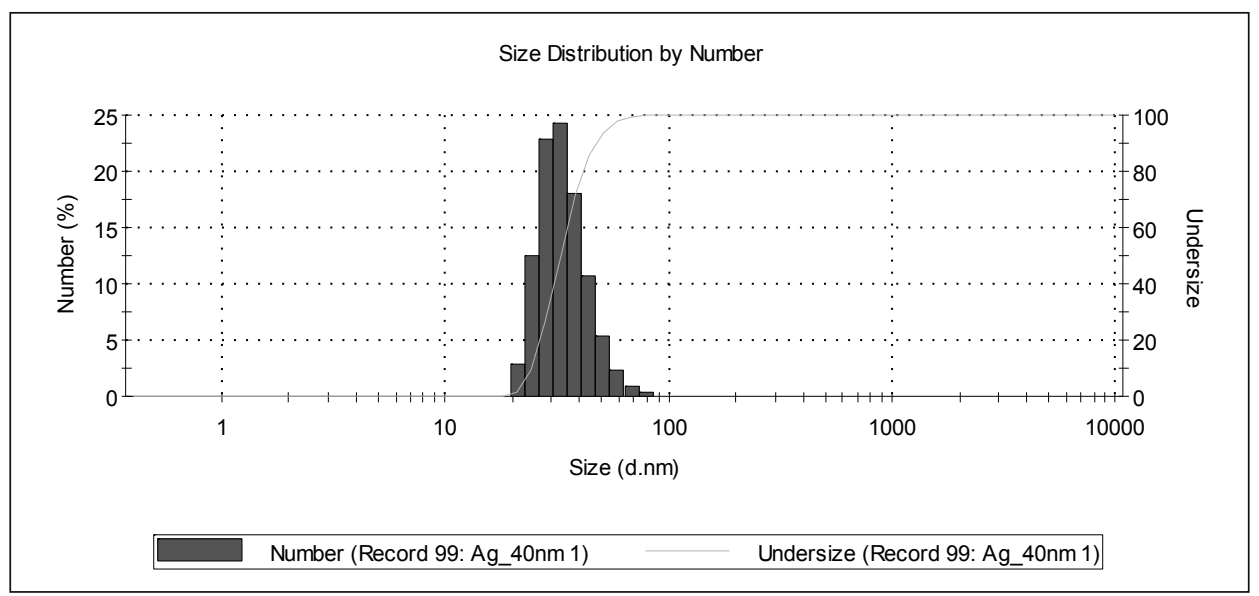

B)

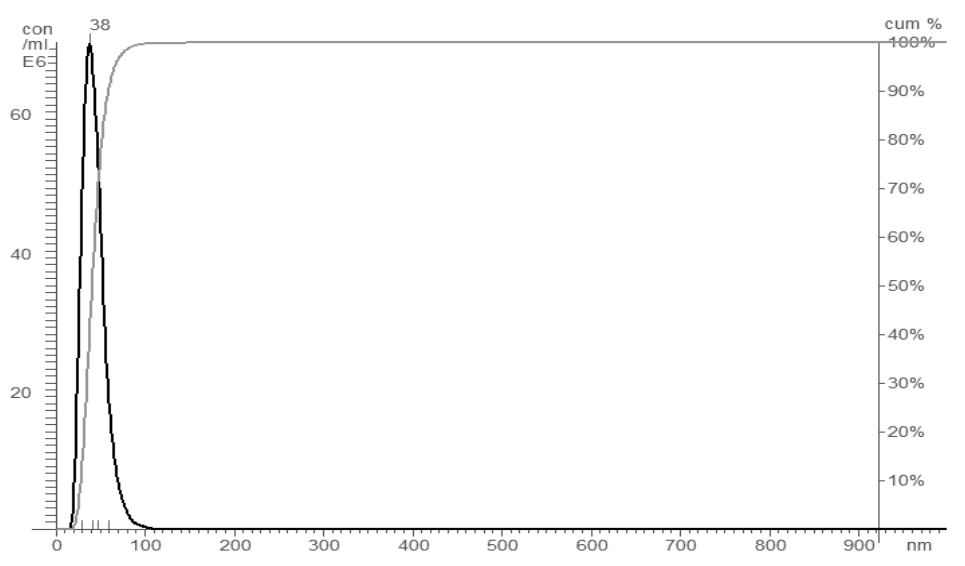

Mean: $44 \mathrm{~nm}$, Mode: $38 \mathrm{~nm}$, SD: $12 \mathrm{~nm}$

Fig. 2. Size distribution by number (in \%) of AgNPs $<40$ in DLS (A) and NTA (B) method 
A)

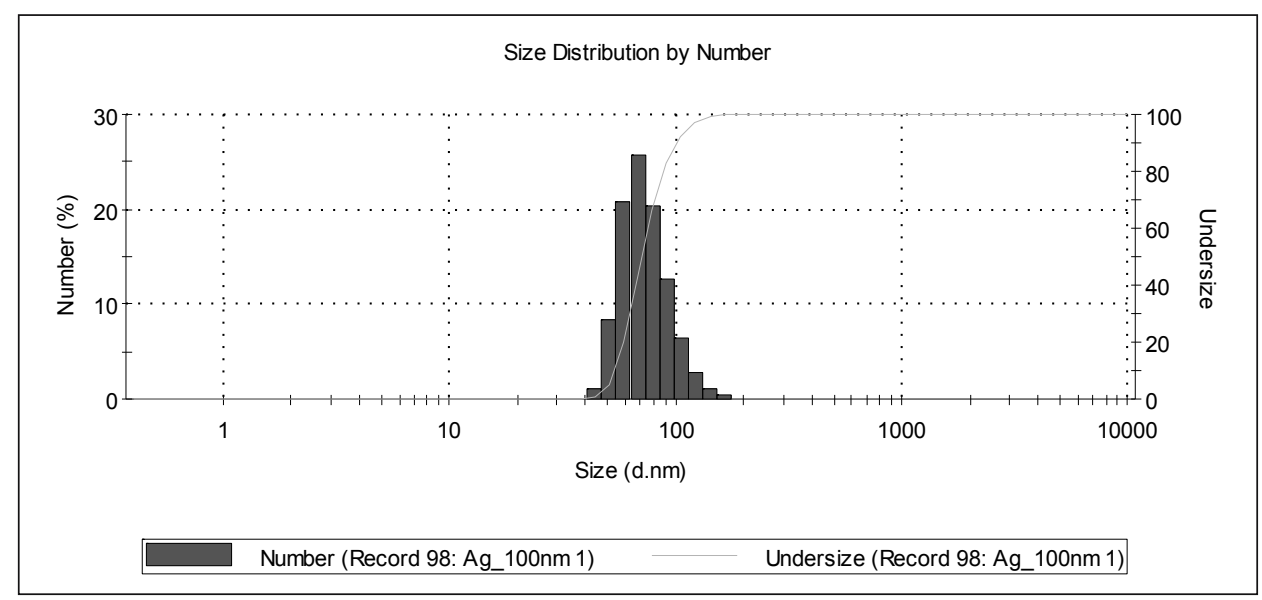

B)

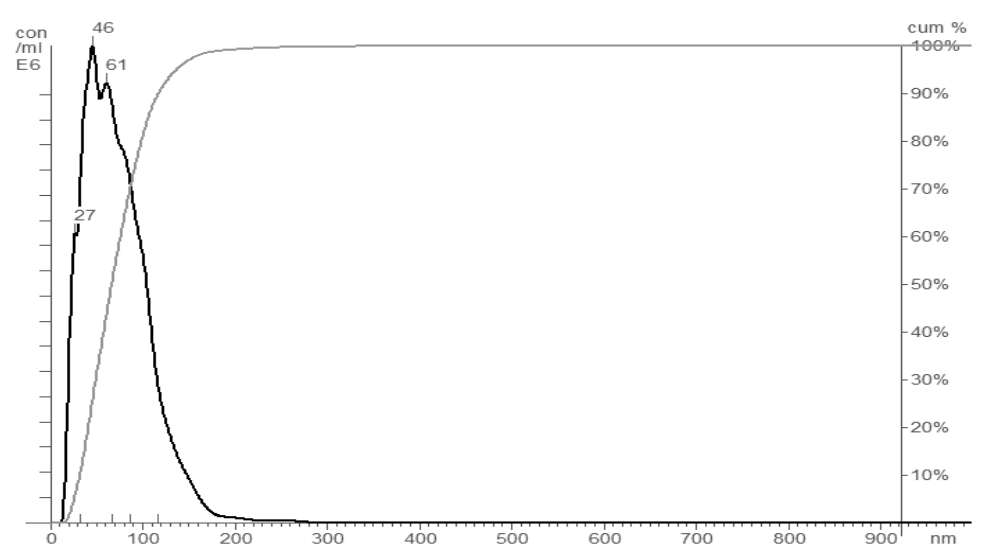

Mean: $73 \mathrm{~nm}$,

Mode: $46 \mathrm{~nm}$, SD: $35 \mathrm{~nm}$

Fig. 3. Size distribution by number (in \%) of AgNPs $<100$ in DLS (A) and NTA (B) method

(Figure 7). This is particularly noticeable in CHO-9 cells, where a comparable level of TAS was observed at the same concentrations of AgNPs (Fig. 7B). Similarly, in 15P-1 cells no fundamental differences between the response of the cells and the size of particles AgNPs at the equivalent concentrations were shown (Fig. 7C). In the case of RAW264.7 cells, the $\mathrm{AgNPs}<100$ did not cause changes in the level of TAS value in comparison to the control (Fig 7A).

\section{Oxidative damage of DNA assessment}

An assessment of oxidative damage to DNA was carried out on CHO-9 cells being exposed to the least toxic particles, i.e.
$\mathrm{AgNPs}<100$. The analysis was carried out using the comet assay under alkaline conditions, through the determination of both single strand-breaks (SSB) of DNA and oxidative damage to DNA alkali recognized by formamido-pyrimidine glycosylase (SSB-FPG). The applied concentrations (2 and $4 \mu \mathrm{g} / \mathrm{ml}$ ) corresponded to cytotoxic concentrations (values close to $\mathrm{IC}_{50}$ and lower) as determined in MTT and NRU assays. The level of DNA damage induced by $\operatorname{AgNPs}<100$ is presented in Table 1. Exposure of CHO-9 cells to silver nanoparticles caused a statistically significant increase in the level of oxidative damage to DNA recognized by FPG as compared to the control (Tab. 1).

Table 1. DNA damage in $\mathrm{CHO}-9$ cells induced by silver nanoparticles AgNPs $<100 \mathrm{~nm}$

\begin{tabular}{|ccccc|}
\hline & \multicolumn{2}{c|}{ DNA damage } \\
\hline \multirow{2}{*}{$A g(\mu \mathrm{g} / \mathrm{ml})$} & \multicolumn{2}{c|}{$\begin{array}{c}\text { DNA fragmentation }(\mathrm{SSB}) \\
(\text { mean } \pm \text { SD) }\end{array}$} & \multicolumn{2}{c|}{$\begin{array}{c}\text { Oxidative DNA damage (FPG) } \\
(\text { mean } \pm \text { SD) }\end{array}$} \\
\cline { 2 - 6 } & Tail DNA $\%$ & $1,04 \pm 0,22$ & Tail DNA\% & Tail moment \\
\hline Control & $8.07 \pm 1.66$ & $17.68 \pm 2.40^{\mathrm{b}}$ & $2,37 \pm 0,56^{\mathrm{b}}$ \\
\hline 2 & $11.68 \pm 4.85$ & $2,38 \pm 0,76$ & $27.21 \pm 2.81^{\mathrm{ab}}$ & $5,66 \pm 1,99^{\mathrm{ab}}$ \\
\hline 4 & $14.58 \pm 5.21$ & $33.85 \pm 9.14^{\mathrm{ab}}$ & $11,17 \pm 2,29^{\mathrm{ab}}$ \\
\hline
\end{tabular}

a - significantly different vs. control $(p<0.05)$ (Student's t-test).

$b$ - significantly different vs. SSB $(p<0.05)$ (Student's t-test). 
A)

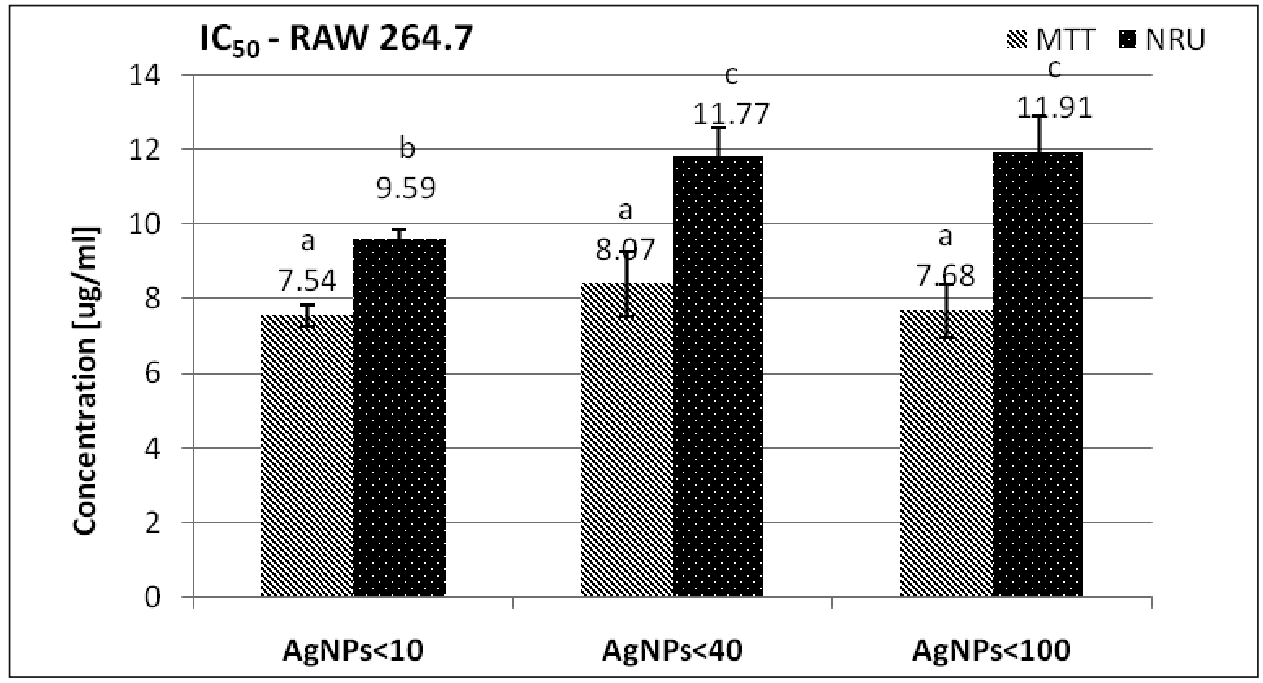

B)

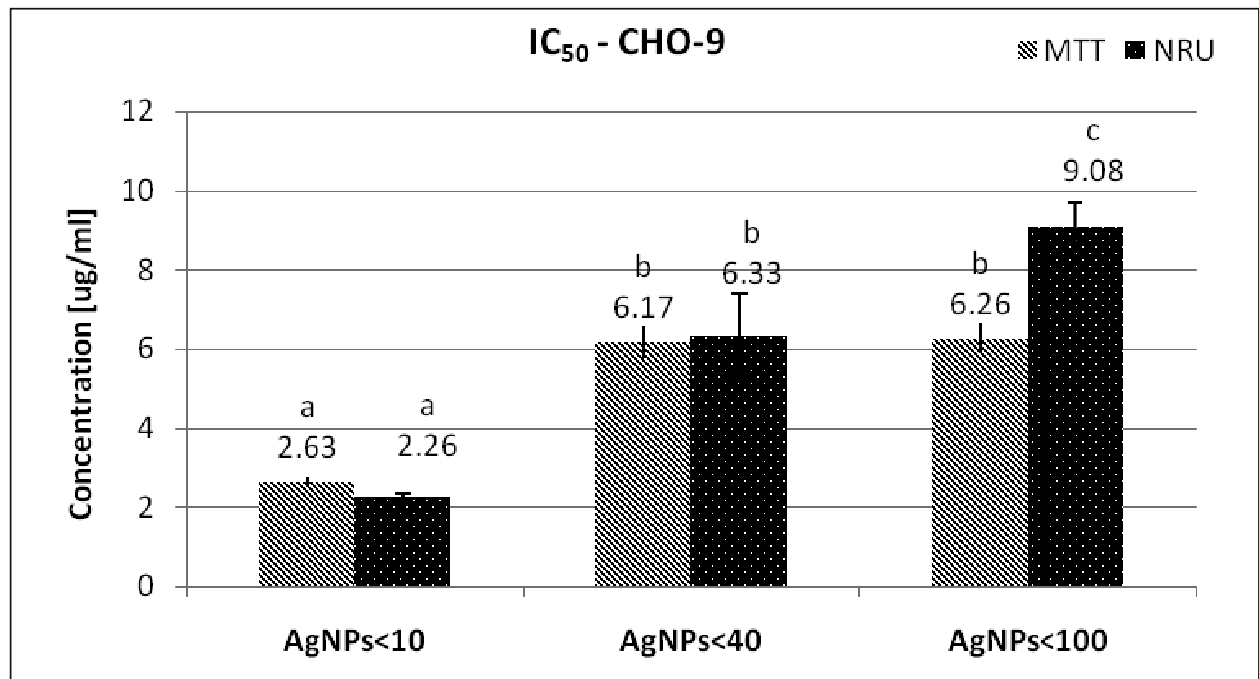

C)

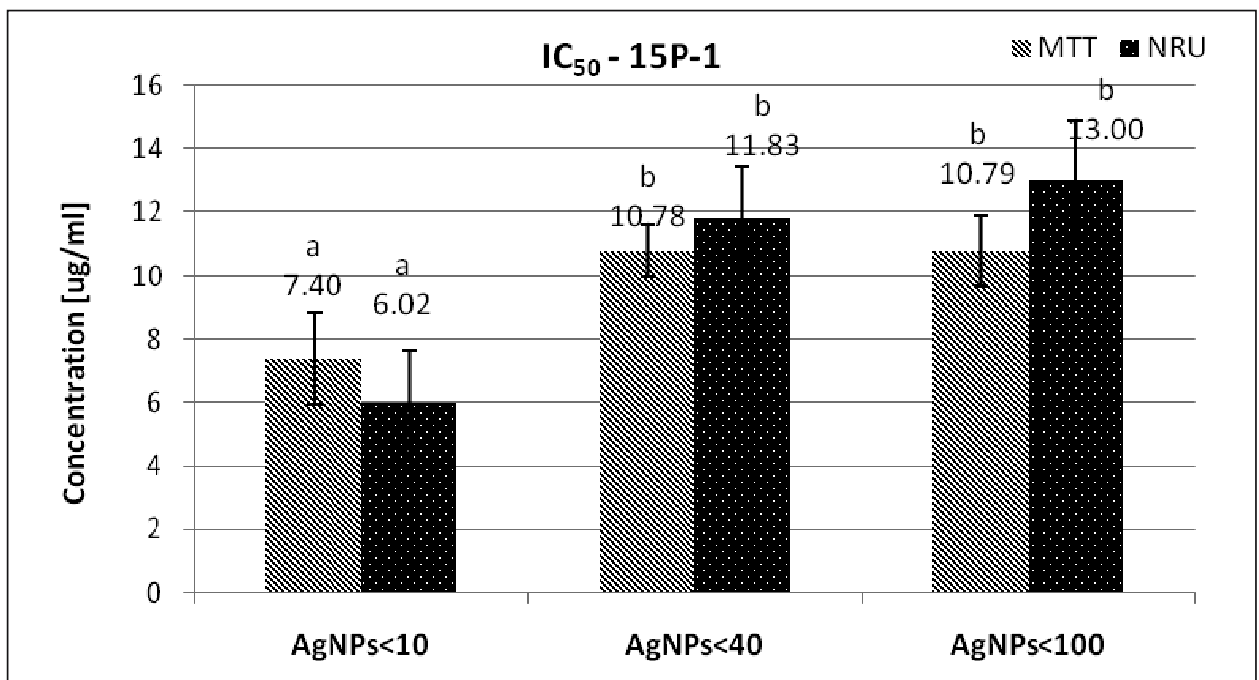

Fig. 4. A comparison the cytotoxic effect of AgNPs on RAW 264.7 (A), CHO-9 (B), and 15P-1(C) cells after $24 \mathrm{~h}$ exposure The cytotoxicity of the AgNPs was determined using NRU or MTT assay and are plotted in order of the concentrations that inhibit cells viability by $50 \%$ compared with controls $\left(\mathrm{IC}_{50}\right.$ values). The value of the control (unexposed) cells was taken as $100 \%$ viability of the cells.

Each bar represents an average value \pm S.D. from at least three independent experiments. In each panel different letters over histograms indicate significantly different values $I C_{50}(P<0.05)$. 
A)

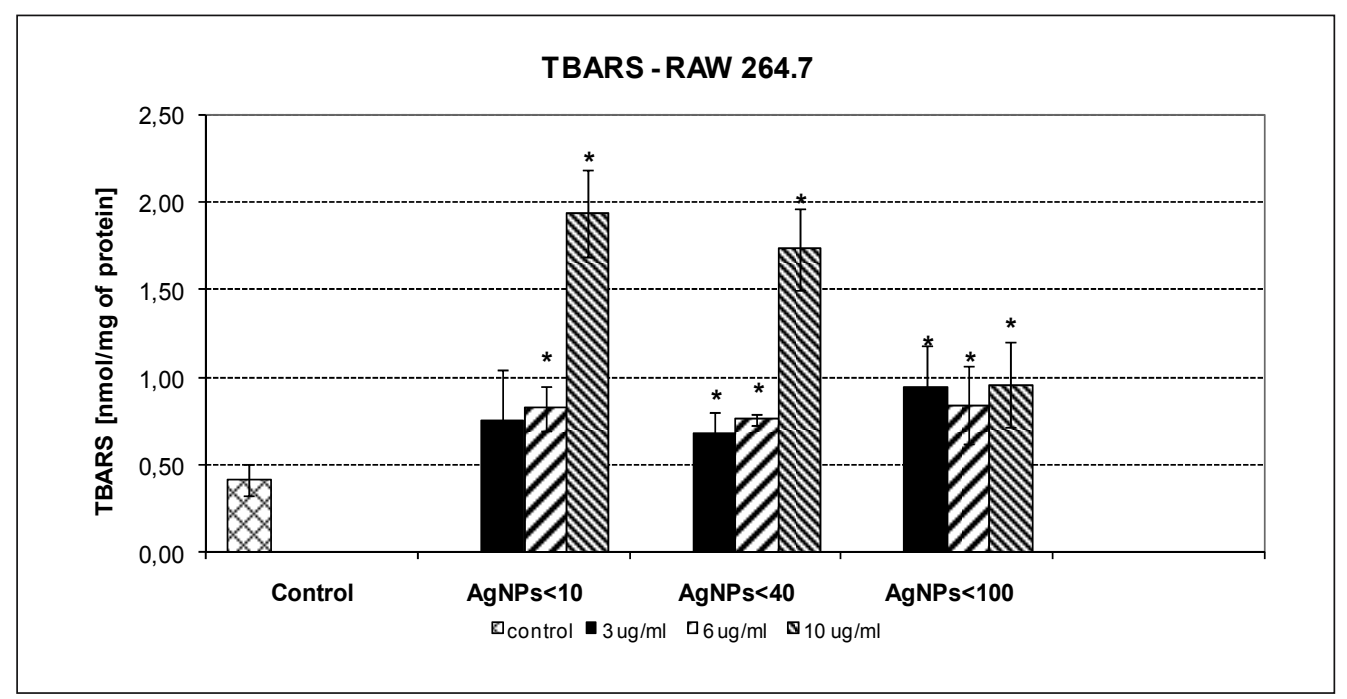

B)

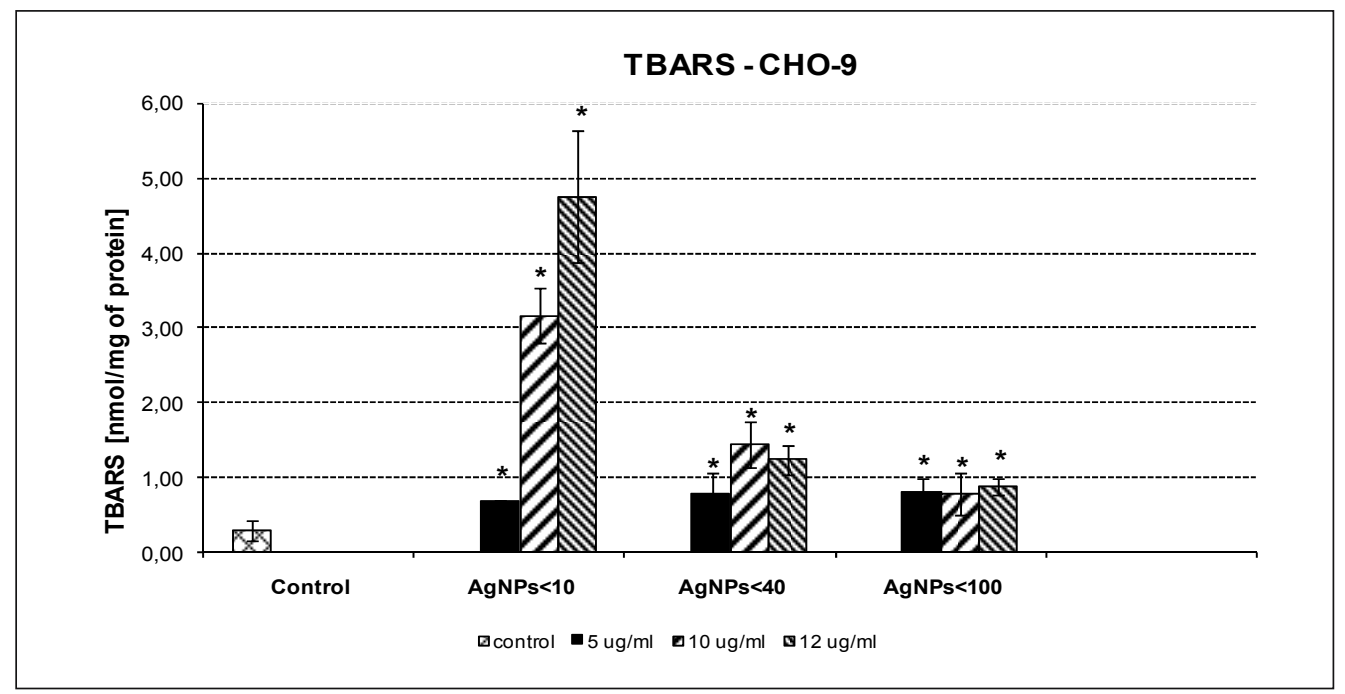

C)

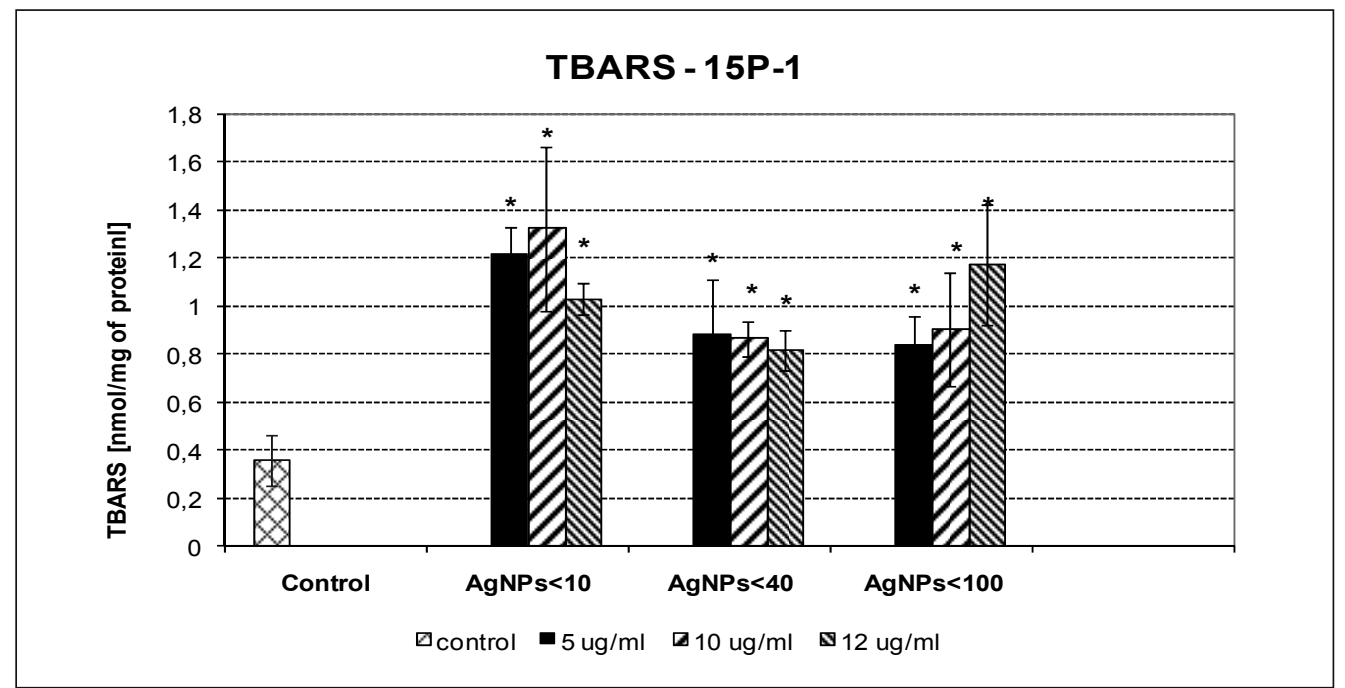

Fig. 5. A comparison the effect of AgNPs on lipid peroxidation in RAW264.7 (A), CHO-9 (B) and 15P-1 (C) cells The cells were treated with different concentration of AgNPs for $24 \mathrm{~h}$ and controls received culture medium only. The thiobarbituric acid assay (TBARS) was used to detect lipid peroxidation. Results expressed as nmol TBARS per mg of protein. Each bar represents an average value \pm SD of at least two independent experiments. The asterisk over histograms indicate significantly different values versus control $(P<0.05)$ 
A)

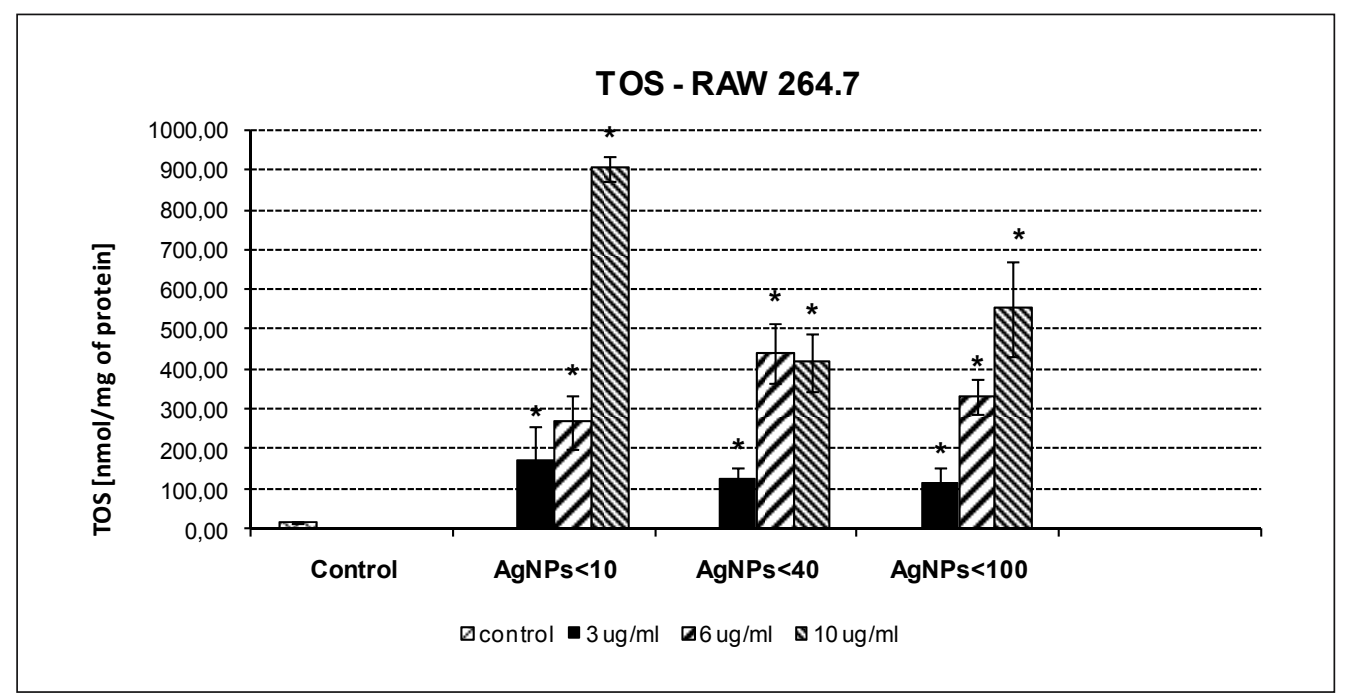

B)

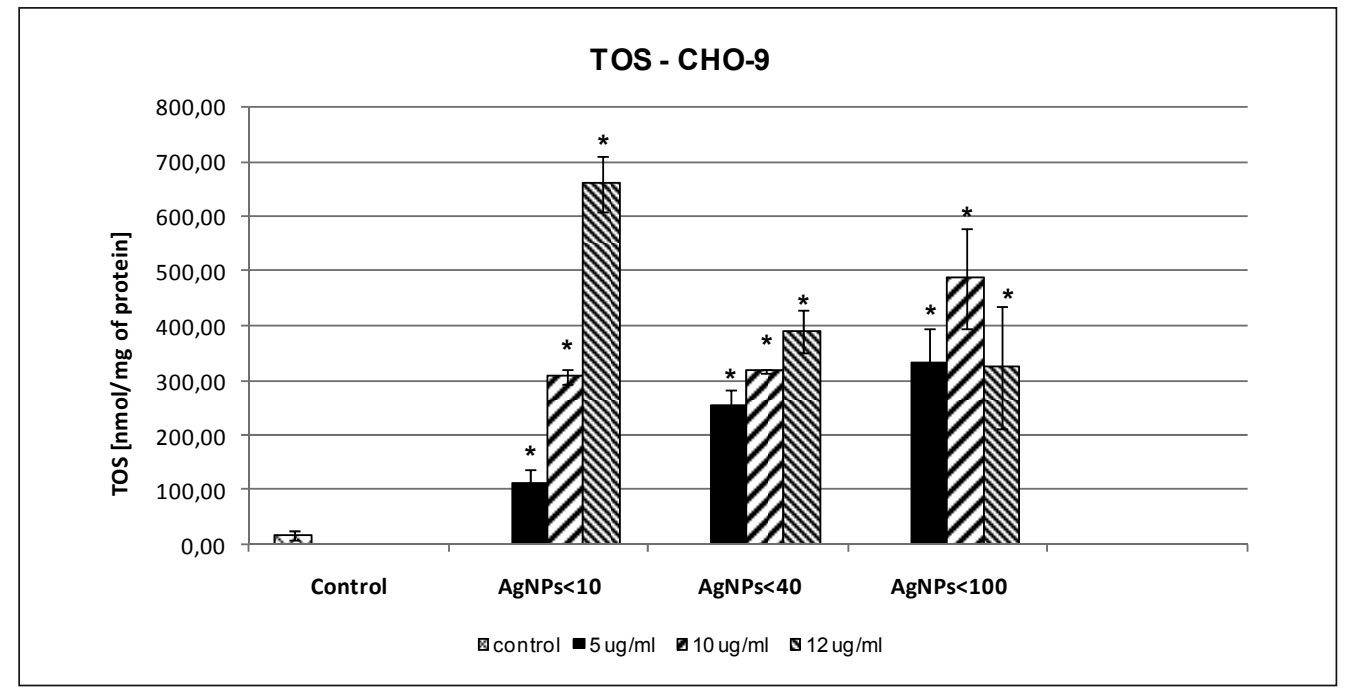

C)

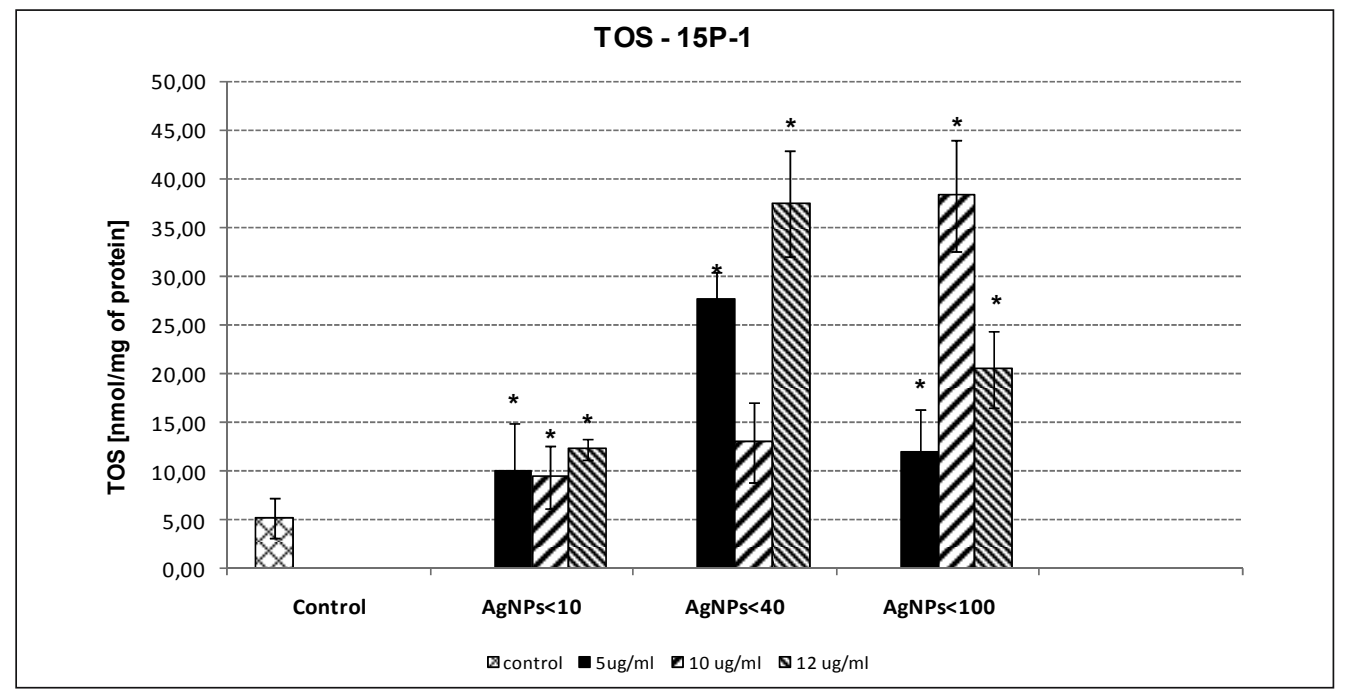

Fig. 6. A comparison the total oxidative status (TOS) in RAW164.7 (A), CHO-9 (B) and 15P-1 (C) cells exposed to AgNPs Cells were treated with different concentrations of AgNPs for $24 \mathrm{~h}$ and controls received culture medium only. Oxidative status was expressed as $\mathrm{H}_{2} \mathrm{O}_{2}$ level in the cells [nmol/mg of protein]. Each bar represents an average value \pm S.D. from three independent experiments.

* Significantly different from untreated control $(P<0.05)$. 
A)

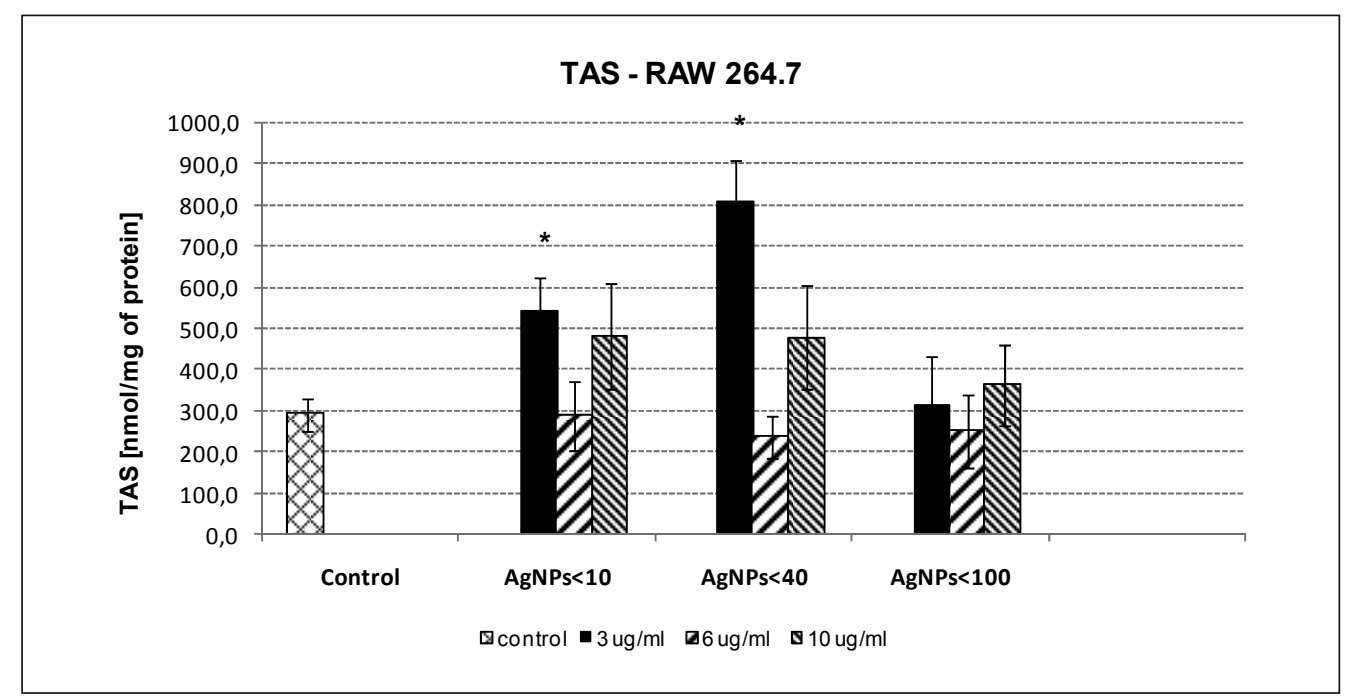

B)

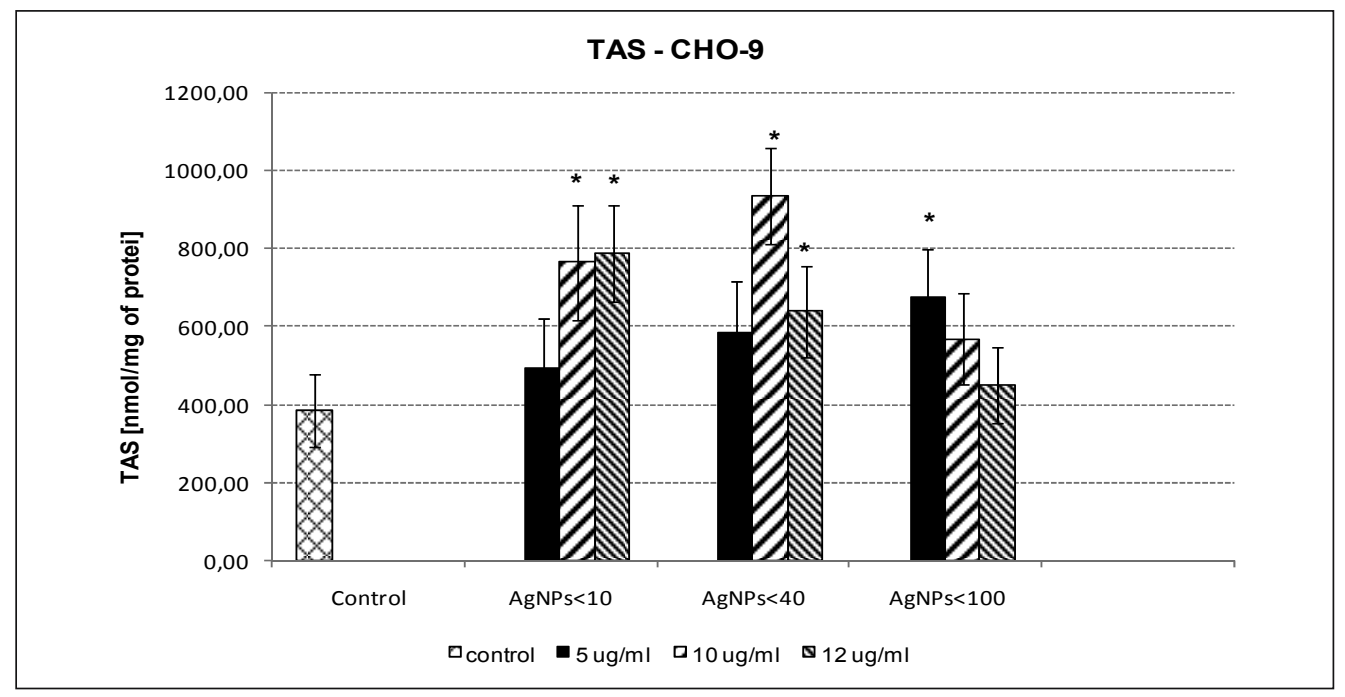

C)

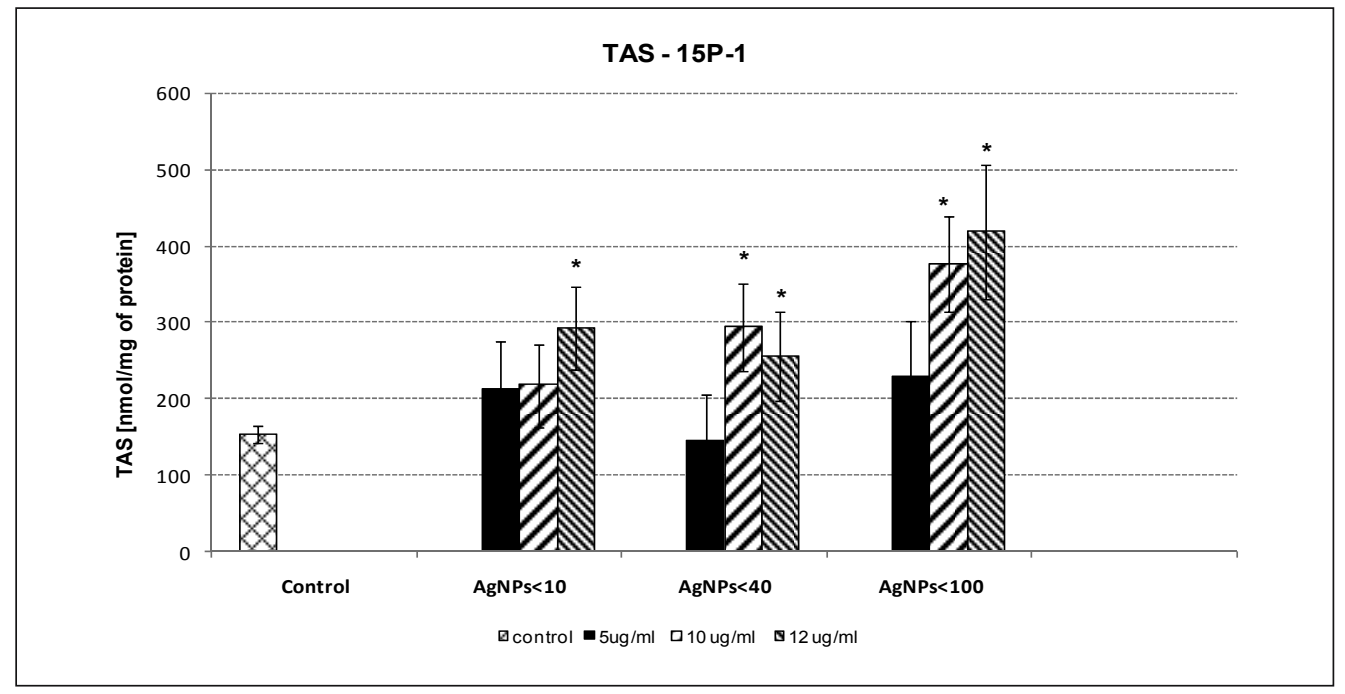

Fig. 7. A comparison the total antioxidative status (TAS) in RAW264.7 (A), CHO-9 (B) and 15P-1 (C) cells exposed to AgNPs Cells were treated with different concentrations of AgNPs for $24 \mathrm{~h}$ and controls received culture medium only.

Antioxidative status was expressed as antioxidants level in the cells [nmol/mg of protein]. Each bar represents an average value \pm S.D.from three independent experiments.

* Significantly different from untreated control $(P<0.05)$. 


\section{Discussion}

Due to widespread applications of nanosilver, human and environmental exposure and the potential risk related to their toxicity increase. Commercial nanosilver is usually available as a suspension in pure de-ionized water with metallic silver nanoparticles of different sizes. The size of nanoparticles is one of the most important factors influencing their toxicity (Lankoff et al. 2012, Montes-Burgos et al, 2010, Jingkun et al. 2009, Teeguarden et al. 2007) but it is known how difficult it is to prepare, in the in vitro assays, a homogeneous suspension of nanoparticles, due to their exceptional ability to aggregate and agglomerate (Bihari et al. 2008, Vippola et al. 2009). This is why the studies were performed on commercially available suspensions of silver, with the assumption that these suspensions are stable and homogeneous. Despite this assumption, the AgNPs were characterized before experiments, in terms of particle size and particle size distribution using two recognized and complementary measurement techniques, namely the DLS and NTA methods (Montes-Burgos et al. 2010, Murdock et al. 2008). Both methods confirmed strong tendency of AgNPs to form aggregates/agglomerates.

In the first place, we assessed the cytotoxic effects of AgNPs. An assessment of the cytotoxicity of nanomaterials is the basic tool in determination of their potential effects at the cellular level. Cytotoxicity studies provide a general picture of the toxic effects of nanoparticles, however different sensitivity of cells needs to be taken into consideration (Lankoff et al. 2012, Barillet et al. 2010). In this study, cell lines with different sensitivity to xenobiotics were used: lung macrophages which play an active role in the process of absorption of dust from pulmonary alveoli as well as in the immune reactions of the body; Sertoli cells (15P-1) which are involved in the formation of the blood-testis barrier; and CHO-9 cells- a suitable model to study the cytotoxic and genotoxic effects of many xenobiotics, including metals (Dopp et al. 2004). All types of cells are capable of phagocytosis, and are considered suitable for studies on dust (Park et al. 2010).

The cytotoxic effects of AgNPs were compared on the basis of the $\mathrm{IC}_{50}$ values as obtained in NRU and MTT assays which measure different parameters of cell damage i.e.cell membrane integrity and lysosomal activity (NRU assay), and mitochondrial metabolic activity (MTT assay). In this study both methods gave similar results. The $\mathrm{IC}_{50}$ values determined for AgNPs fell within the range of $2 \div 13 \mu \mathrm{g} / \mathrm{ml}$, indicating high cytotoxicity all kinds of AgNPs.

At present, there is no general agreement on the cytotoxicity doses of AgNPs in in vitro studies. Some culture cells, for example human adipose-derived stem cells (hASCs), human epidermal keratinocytes, human lung cells (BEAS-2B) exposed to silver nanoparticles for $24 \mathrm{~h}$ (Ag-NPs: $10 \mathrm{~nm}, 20$ $\mathrm{nm}, 50 \mathrm{~nm} ; 80 \mathrm{~nm})$ exhibited cytotoxic effects at concentrations above 50-100 $\mu \mathrm{g} / \mathrm{ml}$ (Samberg et al. 2010, 2012, Gliga et al. 2014). Our results indicate the lower levels of cytotoxicity of AgNPs, and they are consistent with toxic doses received by many researchers in in vitro studies on animal and human cells (skin, lung, liver, colon) (Arora et al. 2008, 2009, Hussain et al 2005, Kim et al. 2009, Liu et al. 2010, Park et al. 2011, Kruszewski et al. 2013, Miethling-Graff et al. 2014). It is worth noting that $\mathrm{IC}_{50}$ values obtained in our experiment were lower or at the same level as the inhibitory doses applied to bacteria as an antibacterial agent (Marambio-Jones and Hoek 2010 and references therein), so such toxicity may be interpreted as a potential hazard to humans.

There is no simply correlation between in vitro data and human exposure, but combined results of both in vitro and in vivo studies could make it possible to extrapolate toxicity for human. For instance, Wang et al. (2014) looked for the relationship between in vitro and in vivo results of inhalation studies and possible human occupational exposure to AgNPs. They calculated that a concentration of $10 \mu \mathrm{g} / \mathrm{mL}$ of AgNPs $(20 \mathrm{~nm})$ would approximately correspond to the total cellular deposition following 74 working weeks ( 8 h per day, 5 days per week). Thus, the doses used should be considered high but likely possible to be reached following long time of exposure, or after acute accidental exposure.

The cytotoxicity doses determined in our experiments are also similar to the toxic doses obtained on animal models recognized as appropriate for ecotoxicological assessment of nanomaterials, for example: fish (Oryzias latipes) (Sohn et al. 2015), zebrafish (Danio rerio) embryos (Asharani et al. 2009, Gao et al. 2015, George et al. 2012), various life stages of rainbow trout (Johari et al. 2013), which indicates that such levels of exposure may pose a real risk to aquatic organisms.

At present, it is estimated that the amount of nanosilver in the environment is relatively low. The use of probabilistic methods for determining the predicted environmental concentrations (PECs) for AgNPs in different environmental compartments, based on the life cycle of products, showed that PECs are at the range of $\mathrm{ng} / \mathrm{L}$ to $\mathrm{mg} / \mathrm{kg}(0.5-2 \mathrm{ng} / \mathrm{L}$ in surface waters; $32-111 \mathrm{ng} / \mathrm{L}$ in sewage treatments plant effluents; $1.3-4.4 \mathrm{mg} / \mathrm{kg}$ in sewage sludge) (Fabrega et al. 2011, Gottschalk and Nowack 2011). Luoma (2008) estimated the concentrations of silver NPs in natural waters range between 0.03 and $500 \mathrm{ng} / \mathrm{l}$. However, in the near future there should be expected an increase in quantities of nano-waste due to the increase of usage of AgNPs. So, the fact that the resulting cytotoxicity doses are higher than those currently found in the environment, does not mean that nanosilver is not hazardous. Besides, it is worth noting, that silver is a metal which has a strong potency to bioaccumulation in sediments and living organisms.

According to our results, three kinds of AgNPs did not exhibit dramatic differences in the cytotoxicity, however the strong tendency to highest toxicity of $\mathrm{AgNPs}<10$ was observed, although these particles were as aggregates/agglomerates. These findings are inconsistent with the results presented by Teeguarden et al. (2007) and Murdock et al. (2008), who reported that only a non-agglomerated NPs would reach the cells and trigger cellular responses. On the other hand, Gosens et al. (2010) reported that the single gold particles do not pose a greater hazard than their agglomerates or slightly larger particles. Lison et al. (2008) also showed that agglomeration state of silica nanoparticles has a little or no significance for the interaction NPs with the cells. Similar results were obtained by Lankoff et al. (2012), who demonstrated that agglomeration state of Ag-NPs had no influence on the cellular binding/uptake in A549 and HepG2 cells. Some authors demonstrated that cell death upon treatment with NPs depends on both cell type and nanoparticle size (Sohaebuddin et al. 2010, Lankoff et al. 2012, Liu et al. 2010, Kruszewski et al. 2013).

According to our results, the cytotoxicity of AgNPs correlated with reactive oxygen species (ROS) generation. The 
AgNPs caused both peroxidation of lipids (TBARS assay) in cells and the formation of reactive oxygen species (TOS assay) and the extent of this changes depended on AgNPs sizes, concentrations and the type of cells. The formation of ROS in cells was accompanied by an increase in the total antioxidant status of cells. However, the ability to produce ROS as assessed on the basis of the determination of the TOS level was higher than the total antioxidant status (TAS), which may indicate the development of oxidative stress in cells.

In most cases, different sizes of AgNPs at equivalent concentrations caused a similar degree of lipid peroxidation. The exception was the level of TBARS determined for AgNPs $<10$ in CHO-9 cells, which indicated a higher toxicity of these particles in comparison to others. The level of TOS value as determined for AgNPs indicates wider relationships between the formation of reactive oxygen species and the particle size; in particular for macrophages, a tendency is observed of smaller Ag particles causing the release of a bigger amount of reactive oxygen species. In the literature on the toxic effects of silver, there is no complete agreement either as to the role of the particle size in the development of oxidative stress or cytotoxic effects. The dependency of the formation of reactive oxygen species (ROS) on the particle size has been demonstrated, for example, in studies on macrophages, colon cells and bacteria (Carlson et al. 2008, Miethling-Graff 2014, Choi and $\mathrm{Hu}$ 2008). However, more and more scientific reports indicate that it is the silver ions that are responsible for the toxic effects of silver nanoparticles (Mukherjee et al. 2012, Park et al. 2010, Marambio-Jones and Hoek 2010, Liu 2010, Kittler et al. 2010). The ionic theory is indirectly related to the particle size, since the smaller the particles, the larger specific surface area they have, the more reactive they are and the more their solubility increases, and thus more ions may be released to the environment (Marambio-Jones and Hoek 2010, Gliga et al. 2014).

Lipid peroxidation and the formation of reactive oxygen species as a result of the effects of silver nanoparticles for all cells under study occurred at concentrations being lower than cytotoxic ones ( $\mathrm{IC}_{50}$ values). This data indicates that the cytotoxic effects of silver nanoparticles result from the activity of reactive oxygen species. Similar data was obtained in the study on cytotoxicity of silver nanoparticles being carried out on macrophages (Carlson et al. 2008), on murine fibroblasts and liver cells (Arora et al. 2009), on cutaneous neoplastic cells (Arora et al. 2008), as well as on cutaneous HaCaT cells and HeLa cells (Mukherjee et al. 2012).

ROS are responsible for oxidative stress in cells, which leads to numerous adverse consequences at the level of both a cell and the entire body. In a cell, ROS may damage proteins, lipids being components of cell membranes, and the genetic material (DNA). One of the sensitive and widely applied methods for the assessment of the extent of DNA damage caused by nanomaterials, is the comet assay (Karlson 2010). The comet assay being performed under alkaline conditions provides a possibility for the identification of strand-breaks at AP (apurinic/apyrimidinic) sites. In order to analyse DNA damage as caused by ROS, the comet assay is performed using specific endonucleases e.g. formamido-pyrimidine glycosylase (FPG) used for the detection of oxidative damage to purine bases of DNA, including 8-oxoguanine. The results of the comet assay demonstrated that ROS being formed in cells as a result of the effects of silver nanoparticles may cause oxidative damage to DNA. Exposure of CHO-9 cells to silver nanoparticles caused a statistically significant increase in the level of oxidative damage to DNA recognized by FPG.

In summary, silver nanoparticles under study had strong cytotoxic effects, caused mitochondrial dysfunction, and an increase in cell membrane permeability. The cytotoxicity was probably mediated by the development of oxidative stress. Reactive oxygen species caused oxidative damage to the genetic material (DNA). The most toxic were particles below $10 \mathrm{~nm}$. Even when the phenomenon of aggregation is taken into account, such results support the finding that nanosilver may present a unique toxicity at low concentrations. Therefore, risks of nanosilver should be considered and appropriate protective measures provided when applying it. This concerns both the work environment where a long term or accidental exposure to AgNPs is possible, and ecosystems, particularly aquatic, where point discharges may result in high local nanosilver concentrations.

\section{Acknowledgements}

The publication has been based on the results of Phase II of the National Programme "Safety and working conditions improvement", funded in the years 2011-2013 in the area of research and development works by the Ministry of Science and Higher Education/The National Centre for Research and Development. We also wish to express our gratitude for the opportunity to conduct SEM and DLS analyses at the Institute of High Pressure Physics of the Polish Academy of Sciences (Warsaw) and for opportunity to conduct Comet Assay at the Institute of Nuclear Chemistry and Technology in Warsaw.

\section{References}

Arora, S., Jain, J., Rajwade, J.M. \& Paknikar, K. (2008). Cellular responses induced by silver nanoparticles: in vitro studies, Toxicology Letters, 179, pp. 93-100. doi:10.1016/j.toxlet.2008.04.009.

Arora, S., Jain, J., Rajwade, J.M. \& Paknikar, K. (2009). Interactions of silver nanoparticles with primary mouse fibroblasts and liver cells, Toxicology and Applied Pharmacology, 236, pp. 310-318. doi:10.1016/j.taap.2009.02.020

Asare, N., Instanes, C., Sandberg, W.J., Refsnes, M., Schwarze, P., Kruszewski, M. \& Brunborg, G. (2012). Cytotoxic and genotoxic effects of silver nanoparticles in testicular cells, Toxicology, 291, pp. $65-72$.

Asharani, P.V., Mun, G.L.K., Hande, M.P. \& Valiyaveettil, S. (2009). Cytotoxicity and genotoxicity of silver nanoparticles in human cells, ACS Nano, 3, pp. 279-290.

Barillet, S., Simon-Deckers, A., Herlin-Boime, N., Mayene-L'Hermite, M., Reynaud, C., Cassio, D., Gouget, B. \& Carriere, M. (2010). Toxicological consequences of $\mathrm{TiO} 2, \mathrm{SiC}$ nanoparticles and multiwalled carbon nanotubes exposure in several mammalian cell types: an in vitro study, Journal of Nanoparticle Research, 12, pp. 61-73.

Beer, C., Foldbjerg, R., Hayashi, Y., Sutherland, D.S. \& Autrup, H. (2012). Toxicity of silver nanoparticles - nanoparticle or silver ion? Toxicology Letters, 208, 3, pp. 286-292.

Bihari, P., Vippola, M., Schultes, S., Praetner, M., Khandoga, A.G., Reichel, C.A., Coester, C., Tuomi, T., Rehberg, M. \& Krombach, F. (2008). Optimized dispersion of nanoparticles for biological in vitro and in vivo studies, Particle and Fibre Toxicology, 5, 14.

Carlson, C., Hussain, S.M., Schrand, A.M., Braydich-Stolle, L.K., Hess, K.L., Jones, R.L. \& Schlager, J.J. (2008). Unique cellular 
interaction of silver nanoparticles: size-dependent generation of reactive oxygen species, The Journal of Physical Chemistry B, 112, pp. 13608-13619. doi:10.1021/jp712087m

Choi, O. \& Hu, Z. (2008). Size dependent and reactive oxygen species related nanosilver toxicity to nitrifying bacteria, Environmental Science \& Technology, 42, pp. 4583-4588. doi:10.1021/es703238h

Colman, B.P., Arnaout, C.L., Anciaux, S., Gunsch, C.K., Hochella, M.F., Kim, B., Lowry, G.V., McGill, B.M., Reinsch, B.C., Richardson, C.J., Unrine, J.M., Wright, J.P., Yin, L. \& Bernhardt, E.S. (2013). Low concentrations of silver nanoparticles in biosolids cause adverse ecosystem responses under realistic field scenario, PLOS ONE, 8(2): e57189. doi:10.1371/journal.pone.0057189.

Commission Staff Working Paper: Types and uses of nanomaterials, including safety aspects. Accompanying the Communication from the Commission to the European Parliament, the Council and the European Economic and Social Committee on the Second Regulatory Review on Nanomaterials., Brussels, 3.10.2012, SWD(2012) 288 final (http://ec.europa.eu/health/ nanotechnology/docs/swd_2012_288_en.pdf. (27.02. 2015)).

Cronholm, P., Karlsson, H.L., Hedberg, J., Lowe, T.A, Winnberg, L., Elihn, K., Wallinder, I.O. \& Möller, L. (2013). Intracellular uptake and toxicity of $\mathrm{Ag}$ and $\mathrm{CuO}$ nanoparticles: a comparison between nanoparticles and their corresponding metal ions, Small, 9, 7, pp. 970-82.

Dopp, E., Hartmann, L.M., Florea, A.M., von Recklinghausen, U., Pieper, R., Shokouhi, B., Rettenmeier, A.W., Hirner, A.V. \& Obe, G. (2004). Uptake of inorganic and organic derivatives of arsenic associated with induced cytotoxic and genotoxic effects in Chinese hamster ovary (CHO) cells, Toxicology and Applied Pharmacology, 1, 201(2), pp. 156-165.

EPA, The Danish Environmental Protection Agency (2015). Exposure assessment of nanomaterials in consumer products. Environmental project No. 1636, (http://www2.mst.dk/Udgiv/ publications/2015/01/978-87-93283-57-2.pdf (6.07.2015)).

Fabrega, J., Luoma, S.N., Tyler, Ch.R., Galloway, T.S. \& Lead, J.R. (2011). Silver nanoparticles: Behaviour and effects in the aquatic environment, Environment International, 37, pp. 517-531.

Gao, J., Sepúlved, M.S., Klinkhamer, C., Wei, A., Gao, Y. \& Mahapatra, C.T. (2015). Nanosilver-coated socks and their toxicity to zebrafish (Danio rerio) embryos, Chemosphere, 119, pp. 948-952. doi: 10.1016/j.chemosphere.2014.08.031.

George, S., Lin, S., Ji, Z., Thomas, C.R., Li, L., Mecklenburg, M., Meng, H., Wang, X., Zhang, H., Xia, T., Hohman, J.N., Lin, S., Zink, J.I., Weiss, P.S. \& Nel, A.E. (2012). Surface defects on plate-shaped silver nanoparticles contribute to its hazard potential in a fish gill cell line and zebrafish embryos, ACS Nano, 6(5) pp. 3745-3759.

Gliga, A.R., Skoglund, S., Wallinder, I.O., Fadeel, B. \& Karlsson, H.L. (2014). Size-dependent cytotoxicity of silver nanoparticles in human lung cells: the role of cellular uptake, agglomeration and Ag release, Particle and Fibre Toxicology, 11, pp. 11. doi: 10.1186/1743-8977-11-11

Gosens, I., Post, J.A., de la Fonteyne, L.J., Jansen, E.H., Geus, J.W., Cassee, F.R. \& de Jong, W.H. (2010). Impact of agglomeration state of nano- and submicron sized gold particles on pulmonary inflammation, Particle and Fibre Toxicology, 7, 37.

Gottschalk, F. \& Nowack, B. (2011). The release of engineered nanomaterials to the environment, Journal of Environmental Monitoring, 13 (5), pp. 1145-1155.

Hussain, S.M., Hess, K.L., Gearhart, J.M., Geiss, K,T. \& Schlager, J.J. (2005). In vitro toxicity of nanoparticles in BRL 3A rat liver cells, Toxicology in Vitro, 19, pp. 975-983.

Impellitteri, C.A., Harmon, S., Silva, R.G., Miller, B.W., Scheckel, K.G., Luxton, T.P., Schupp, D. \& Panguluri, S. (2013). Transformation of silver nanoparticles in fresh, aged, and incinerated biosolids, Water Research, 4, 7, pp. 3878-3886.
INVITTOX Protocol No 17: MTT Assay (1990) The ERGATT/ FRAME Data Bank of In Vitro Techniques in Toxicology, Nottingham, 1990.

INVITTOX Protocol No 64: The Neutral Red Cytotoxicity Assay (1992) The ERGATT/FRAME Data Bank of In Vitro Techniques in Toxicology, Nottingham, 1992.

Jankowska, E. \& Łukaszewska, J. (2013). Potential exposure to silver nanoparticles during spraying pereparation for air-conditioning cleaning, Medycyna Pracy, 64 (1), pp. 57-67. (in polish)

Jiao, Z-H., Li, M., Feng, Y-X., Shi, J-Ch., Zhang, J. \& Shao, B. (2014). Hormesis effects of silver nanoparticles at non-cytotoxic doses to human hepatoma cells, PLoS ONE, 9(7): e102564.

Jingkun, J., Oberdorster, G. \& Pratim, B. (2009). Characterization of size, surface charge, and agglomeration state of nanoparticle dispersions for toxicological studies, Journal of Nanoparticles Research, 11, pp. 77-89.

Johari, S.A., Kalbassi, M.R., Soltani, M. \& Yu, I.J. (2013). Toxicity comparison of colloidal silver nanoparticles in various life stages of rainbow trout (Oncorhynchus mykiss), Iranian Journal of Fisheries Sciences, 12 (1), pp. 76-95.

Kaegi, R., Voegelin, A., Ort, Ch., Sinnet, B., Thalmann, B., Krismer, J., Hagendorfer, H., Elumelu, M. \& Mueller, E. (2013). Fate and transformation of silver nanoparticles in urban wastewater systems, Water Research, 47 (12), pp. 3866-3877.

Kaegi, R., Voegelin, A., Sinnet, B., Zuleeg, S., Hagendorfer, H., Burkhardt, M. \& Siegrist, H. (2011). Behavior of metallic silver nanoparticles in a pilot wastewater treatment plant, Environmental Science \& Technology, 45 (9), pp. 3902-3908. doi: $10.1021 /$ es 1041892

Karlsson, H.L. (2010). The comet assay in nanotoxicology research, Analytical and Bioanalytical Chemistry, 398(2), pp. 651-666.

Kim, B., Park, C.S., Murayama, M. \& Hochella, M.F. (2010). Discovery and characterization of silver sulfide nanoparticles in final sewage sludge products, Environmental Science \& Technology, 44 (19), pp. 7509-7514. doi: 10.1021/es101565j.

Kim, S., Choi, J.E., Chung, K.-H., Park, K., Yi, J. \& Ryu, D.-Y. (2009). Oxidative stress-dependent toxicity of silver nanoparticles in human hepatoma cells, Toxicology In Vitro, 23, pp. 1076-1084.

Kim, T.H., Kim, M., Park, H.S., Shin, U.S., Gong, M.S. \& Kim, H.W. (2012). Size-dependent cellular toxicity of silver nanoparticles, Journal of Biomedical Materials Research A, 100, pp. 1033-1043.

Kim, Y.-J., Yang, S.I. \& Ryu, J.-Ch. (2010). Cytotoxicity and genotoxicity of nano-silver in mammalian cell lines, Molecular and Cellular Toxicology, 6(2), pp. 119-125.

Kittler, S., Greulich, C., Diendorf, J., Koller, M. \& Epple, M. (2010). Toxicity of silver nanoparticles increases during storage because of slow dissolution under release of silver ions, Chemistry of Materials, 22, pp. 4548-4554.

Kruszewski, M., Grądzka, I., Bartłomiejczyk, T., Chwastowska, J., Sommer, S., Grzelak, A., Zuberek, M., Lankoff, A., Dusinska, M. \& Wojewodzka, M. (2013). Oxidative DNA damage corresponds to the long term survival of human cells treated with silver nanoparticles, Toxicology Letters, 219, pp. 151-159.

Lankoff, A., Sandberg, W.J., Wegierek-Ciuk, A., Lisowska, H., Refsnes, M., Sartowska, B., Schwarze, P.E., Meczynska-Wielgosz, S., Wojewodzka, M. \& Kruszewski, M. (2012). The effect of agglomeration state of silver and titanium dioxide nanoparticles on cellular response of HepG2, A549 and THP-1 cells, Toxicology Letters, 208, pp. 197-213.

Levard, C., Reinsch, B.C., Michel, F.M., Oumahi, C., Lowry, G.V. \& Brown, G.E. (2011). Sulfidation processes of PVP-coated silver nanoparticles in aqueous solution: impact on dissolution rate, Environmental Science \& Technology, 45, pp. 5260-5266.

Levard, C., Hotze, E.M., Colman, B.P., Dale, A.L., Truong, L., Yang, X.Y., Bone, A.J., Brown, G.E., Tanguay, R.L., Di Giulio, R.T., Bernhardt, E.S., Meyer, J.N., Wiesner, M.R. \& Lowry, 
G.V. (2013). Sulfidation of silver nanoparticles: natural antidote to their toxicity, Environmental Science \& Technology, 47(23), pp. 13440-13448. doi: 10.1021/es403527n.

Lison, D., Thomassen, L.C., Rabolli, V., Gonzalez, L., Napierska, D., Seo, J.W., Kirsch-Volders, M., Hoet, P., Kirschhock, C.E. \& Martens, J.A. (2008). Nominal and effective dosimetry of silica nanoparticles in cytotoxicity assays, Toxicological Sciences, 104, pp. 155-162.

Liu, W., Wu, Y., Wang, C., Li, H.C., Wang, T., Liao, C.Y., Cui, L., Zhou, Q.F., Yan, B. \& Jiang, G.B. (2010). Impact of silver nanoparticles on human cells: effect of particle size, Nanotoxicology, 4(3), pp. 319-330.

Luoma, S.N. (2008). Silver nanotechnologies and the environment: old problems or new challenges? PEN 15. The Project on Emerging nanotechnologies. (http://www.nanotechproject.org (27.02.2015)).

Manke, A., Wang, L. \& Rojanasakul, Y. (2013). Mechanisms of nanoparticle-induced oxidative stress and toxicity, BioMed Research International, 2013, 20, ID 942916. http://dx.doi. org/10.1155/2013/942916.

Marambio-Jones, C. \& Hoek, E.M. (2010). A review of the antibacterial effects of silver nanomaterials and potential implications for human health and the environment, Journal of Nanoparticles Research, 12, pp. 1531-1551. Doi: 10.1007/s11051-010-9900-y.

Miethling-Graff, R., Rumpker, R., Richter, M., Verano-Braga, T., Kjeldsen, F., Brewer, J., Hoyland, J., Rubahn, H.-G. \& Erdmann, H. (2014). Exposure to silver nanoparticles induces size- and dose-dependent oxidative stress and cytotoxicity in human colon carcinoma cells, Toxicology in Vitro, 28, pp.1280-1289.

Moaddab, S., Ahari, H., Shahbazzadeh, D., Motallebi, A.A., Anvar, A.A., Rahman-Nya,. J. \& Shokrgozar, M.R. (2011).Toxicity study of nanosilver (nanocid) on osteoblast cancer cell line, International Nano Letters, 1, pp. 11-16.

Montes-Burgos, I., Walczyk, D., Hole, P., Smith, J., Lynch, I. \& Dawson, K. (2010). Characterisation of nanoparticle size and state prior to nanotoxicological studies, Journal of Nanoparticles Research, 12, pp. 47-53. doi: 10.1007/s11051-009-9774-z.

Mukherjee, S.G., O'Claonadh, N., Casey, A. \& Chambers, G. (2012). Comparative in vitro cytotoxicity study of silver nanoparticle on two mammalian cell lines, Toxicology iv Vitro, 26, pp. 238-251.

Murdock, R.C., Braydich-Stolle, L., Schrand, A.M., Schlager, J.J. \& Hussain, S.M. (2008). Characterization of nanomaterial dispersion in solution prior to in vitro exposure using dynamic light scattering technique, Toxicological Sciences, 101, pp. 239-253.

Park, E.J., Yi ,J., Kim, Y., Choi, K. \& Park, K. (2010). Silver nanoparticles induce cytotoxicity by a Trojan-horse type mechanism, Toxicology In Vitro, 24, pp. 872-878.

Park, M.V., Neigh, A.M., Vermeulen, J.P., de la Fonteyne, L.J., Verharen, H.W., Briede, J.J., Van, L.H. \& De Jong, W.H. (2011). The effect of particle size on the cytotoxicity, inflammation, developmental toxicity and genotoxicity of silver nanoparticles, Biomaterials, 32, pp. 9810-9817.

Samberg, M.E, Loboa, E.G., Oldenburg, S.J \& Monteiro-Riviere, N.A. (2012). Silver nanoparticles do not influence stem cell differentiation but cause minimal toxicity, Nanomedicine, 7(8), pp. 1197-1209.

Samberg, M.E, Oldenburg, S.J. \& Monteiro-Riviere, N.A. (2010). Evaluation of silver nanoparticle toxicity in skin in vivo and keratinocytes in vitro, Environmental Health Perspectives, 118(3), pp. 407-413.

SCENIHR (Scientific Committee on Emerging and Newly Identified Health Risks), 2014. Nanosilver: safety, health and environmental effects and role in antimicrobial resistance. (http://ec.europa.eu/ health/scientific_committees/emerging/docs/scenihr_o_039.pdf (03.07.2015)).

Schlich, K., Klawonn, T., Terytze, K. \& Hund-Rinke, K. (2013). Hazard assessment of a silver nanoparticle in soil applied via sewage sludge, Environmental Sciences Europe, 25: 17. doi:10.1186/2190-4715-25-17.

Senjen, R., FoE Australia \& Ian Illuminato, FoE U.S (2009). Nano and Biocidal Silver. Extreme germ killers present a growing threat to public health. Nanosilver Report, Health Care Without Harm Europe (HCWHE) (http://www.shrimpnews.com/PDFsFolder/ VietnamNanoSilverSolutions.pdf (27.02.2015)).

Sheehy, K., Casey, A., Murphy, A. \& Chambers, G. (2015). Antimicrobial properties of nano-silver: A cautionary approach to ionic interference, Journal of Colloid and Interface Science, 443, pp. 56-64. doi:10.1016/j.jcis.2014.11.074.

SIGMA, (http://www.sigmaaldrich.com/materials-science/nanomaterials/ silver-nanoparticles.html\#sthash.GcKXIXiP.dpuf (08.09.2016)).

Singh, R.P. \& Ramaro, P. (2012). Cellular uptake, intracellular trafficking and cytotoxicity of silver nanoparticles, Toxicology Letters, 213(2), pp. 249-259. doi: 10.1016/j.toxlet.2012.07.009.

Sohaebuddin, S.K., Thevenot, P.T., Baker, D., Eaton, J.W. \& Tang, L. (2010). Nanomaterial cytotoxicity is composition, size, and cell type dependent, Particle and Fibre Toxicology, 21, pp. 7-22. doi: 10.1186/1743-8977-7-22.

Sohn, E.K., Johari, S.A., Kim, T.G., Kim, J.K., Kim, E., Lee, J.H., Chung, Y.S. \& Yu, I.J. (2015). Aquatic toxicity comparison of silver nanoparticles and silver nanowires, BioMed Research International, 2015: 893049. doi: 10.1155/2015/893049.

Teeguarden, G., Hinderliter, P.M., Orr, G., Thrall, B.D. \& Pounds, J.G. (2007). Particokinetics in vitro: dosimetry considerations for in vitro nanoparticle toxicity assessments, Toxicological Sciences, 95, pp. 300-312.

Verano-Braga, T., Miethling-Graff, R., Wojdyla, K., Rogowska-Wrzesinska, A., Brewer, J.R., Erdmann, H. \& Kjeldsen, F. (2014). Insights into the cellular response triggered by silver nanoparticles using quantitative proteomics, ACS Nano, 8 (3), pp. 2161-2175.

Vippola, M., Falc, G.C.M., Lindberg, H.K., Suhonen, S., Vanhala, E., Norppa, H., Savolainen, K., Tossavainen, A. \& Tuomi, T. (2009). Preparation of nanoparticle dispersions for in-vitro toxicity testing, Human and Experimental Toxicology, 28, pp. 377-385.

Wang, H., Wu, L. \& Reinhard, B.M. (2012). Scavenger receptor mediated endocytosis of silver nanoparticles into J774A.1 macrophages is heterogeneous, ACS Nano, 6(8), pp. 7122-7132. doi: 10.1021/nn302186n.

Wang, X., Ji Z., Chang, C.H., Zhang, H., Wang, M., Liao, Y.P., Lin, S., Meng, H., Li, R., Sun, B., Van Winkle, L., Pinkerton, K.E., Zink, J.I., Xia, T. \& Nel, A.E. (2014). Use of coated silver nanoparticles to understand the relationship of particle dissolution and bioavailability to cell and lung toxicological potential, Small, 29(10), pp. 389-398. doi: 10.1002/smll.201301597.

Wijnhoven, S.W.P., Peijnenburg, W.J.G.M., Herberts, C.A., Hagens, W.I., Oomen, A.G., Heugens, E.H.W., Roszek, B., Bisschops, J., Gosens, I., van de Meent, D., Dekkers, S., de Jong, W.H., van Zijverden, M., Sips, A.J.A.M. \& Geertsma, R.E. (2009). Nano-silver - a review of available data and knowledge gaps in human and environmental risk assessment, Nanotoxicology, 3, pp. 109-138.

Wojewodzka, M., Kruszewski, M., Iwanenko, T., Collins, A.R. \& Szumiel, I. (1998). Application of the comet assay for monitoring DNA damage in workers exposed to chronic low-dose irradiation. I. Strand breakage, Mutation Research, 416, pp. 21-35. 


\title{
Wpływ różnej wielkości nanocząstek srebra \\ na cytotoksyczność i zaburzenia metabolizmu tlenowego w komórkach układu oddechowego i rozrodczego
}

\begin{abstract}
Streszczenie: Nanocząstki srebra (AgNPs), ze względu na silne właściwości bakteriobójcze, mają szerokie zastosowanie w wielu dziedzinach przemysłu, biomedycynie i produktach konsumenckich. Rozmiar cząstek jest istotnym, ale wciąż niewystarczająco zbadanym parametrem wpływającym na toksyczność nanosrebra. W pracy oceniono toksyczne działanie różnej wielkości cząstek srebra $(\sim 10,40$ i $100 \mathrm{~nm})$ na komórki układu rozrodczego i oddechowego (CHO-9, 15P-1 i RAW264.7). Badano wpływ AgNPs na przeżywalność komórek, przepuszczalność błon komórkowych i aktywność metaboliczną komórek, zaburzenia metabolizmu tlenowego oraz odległe skutki działania w postaci uszkodzeń materiału genetycznego (DNA). Wszystkie badane AgNPs wykazywały silne działanie cytotoksyczne, w zakresie niskich stężeń $(2 \div 13 \mu \mathrm{g} / \mathrm{ml})$ oraz powodowały powstawanie stresu oksydacyjnego w komórkach w stężeniach niższych niż cytotoksyczne. Powstające w komórkach reaktywne formy tlenu powodowały oksydacyjne uszkodzenia DNA wykrywane w teście kometowym. Najsilniejsze działanie wykazywały cząstki o wielkości $<10 \mathrm{~nm}$. Otrzymane wyniki wskazują, że nanocząstki srebra, zwłaszcza poniżej $10 \mathrm{~nm}$, mogą stanowić zagrożenie dla organizmów. Dlatego też należy rozważyć ryzyko stosowania preparatów z nanosrebrem i zapewnić środki zapobiegające ich niekontrolowanemu uwalnianiu.
\end{abstract}

